\title{
Bromine atom production and chain propagation during springtime Arctic ozone depletion events in Barrow, Alaska
}

\author{
Chelsea R. Thompson ${ }^{1, \mathrm{a}, \mathrm{b}}$, Paul B. Shepson ${ }^{1,2}$, Jin Liao ${ }^{3, \mathrm{c,d}}$, L. Greg Huey ${ }^{3}$, Chris Cantrell ${ }^{4, \mathrm{e}}$, Frank Flocke ${ }^{4}$, and \\ John Orlando 4 \\ ${ }^{1}$ Department of Chemistry, Purdue University, West Lafayette, IN, USA \\ ${ }^{2}$ Department of Earth and Atmospheric Sciences and Purdue Climate Change Research Center, Purdue University, \\ West Lafayette, IN, USA \\ ${ }^{3}$ School of Earth and Atmospheric Sciences, Georgia Institute of Technology, Atlanta, GA, USA \\ ${ }^{4}$ National Center for Atmospheric Research, Boulder, CO, USA \\ anow at: Cooperative Institute for Research in Environmental Sciences, University of Colorado Boulder, Boulder, CO, USA \\ b now at: Chemical Sciences Division, NOAA Earth System Research Laboratory, Boulder, CO, USA \\ ${ }^{\mathrm{c}}$ now at: Atmospheric Chemistry and Dynamics Laboratory, NASA Goddard Space Flight Center, Greenbelt, MD, USA \\ ${ }^{d}$ now at: Universities Space Research Association, Columbia, MD, USA \\ enow at: Department of Atmospheric and Ocean Sciences, University of Colorado Boulder, Boulder, CO, USA
}

Correspondence to: Chelsea R. Thompson (chelsea.thompson@noaa.gov)

Received: 22 December 2015 - Discussion started: 18 January 2016

Revised: 1 November 2016 - Accepted: 9 February 2017 - Published: 9 March 2017

\begin{abstract}
Ozone depletion events (ODEs) in the Arctic are primarily controlled by a bromine radical-catalyzed destruction mechanism that depends on the efficient production and recycling of $\mathrm{Br}$ atoms. Numerous laboratory and modeling studies have suggested the importance of heterogeneous recycling of $\mathrm{Br}$ through $\mathrm{HOBr}$ reaction with bromide on saline surfaces. On the other hand, the gas-phase regeneration of bromine atoms through $\mathrm{BrO}-\mathrm{BrO}$ radical reactions has been assumed to be an efficient, if not dominant, pathway for $\mathrm{Br}$ reformation and thus ozone destruction. Indeed, it has been estimated that the rate of ozone depletion is approximately equal to twice the rate of the $\mathrm{BrO}$ self-reaction. Here, we use a zero-dimensional, photochemical model, largely constrained to observations of stable atmospheric species from the 2009 Ocean-Atmosphere-Sea Ice-Snowpack (OASIS) campaign in Barrow, Alaska, to investigate gas-phase bromine radical propagation and recycling mechanisms of bromine atoms for a 7-day period during late March. This work is a continuation of that presented in Thompson et al. (2015) and utilizes the same model construct. Here, we use the gas-phase radical chain length as a metric for objectively quantifying the efficiency of gas-phase recycling of bromine atoms. The gas-phase bromine chain length is de-
\end{abstract}

termined to be quite small, at $<1.5$, and highly dependent on ambient $\mathrm{O}_{3}$ concentrations. Furthermore, we find that $\mathrm{Br}$ atom production from photolysis of $\mathrm{Br}_{2}$ and $\mathrm{BrCl}$, which is predominately emitted from snow and/or aerosol surfaces, can account for between 30 and $90 \%$ of total Br atom production. This analysis suggests that condensed-phase production of bromine is at least as important as, and at times greater than, gas-phase recycling for the occurrence of Arctic ODEs. Therefore, the rate of the $\mathrm{BrO}$ self-reaction is not a sufficient estimate for the rate of $\mathrm{O}_{3}$ depletion.

\section{Introduction}

The springtime depletion of boundary layer ozone in the Arctic has been the subject of intense research for several decades. Early observations revealed a strong correlation between ozone depletion events (ODEs) and enhancements in filterable bromine (Barrie et al., 1988). This discovery led researchers to propose a mechanism for the bromine-catalyzed destruction of ozone. 
$\mathrm{Br}_{2}+h v \rightarrow 2 \mathrm{Br}$

$\mathrm{Br}+\mathrm{O}_{3} \rightarrow \mathrm{BrO}+\mathrm{O}_{2}$

$\mathrm{BrO}+\mathrm{BrO} \rightarrow \mathrm{Br}_{2}($ or $\mathrm{Br}+\mathrm{Br})+\mathrm{O}_{2}$

This reaction cycle requires an initial source of bromine atoms to the boundary layer. Laboratory and theoretical studies have suggested that $\mathrm{Br}_{2}$ could be produced through oxidation of bromide present in salt-enriched snow, ice, or aerosol surfaces by gas-phase ozone (Hirokawa et al., 1998; Oum et al., 1998b; Gladich et al., 2015).

$\mathrm{O}_{3}+2 \mathrm{Br}_{(\mathrm{aq})}^{-}+2 \mathrm{H}_{(\mathrm{aq})}^{+} \rightarrow \rightarrow \mathrm{Br}_{2}+\mathrm{O}_{2}+\mathrm{H}_{2} \mathrm{O}$

Field observations by Pratt et al. (2013) using a controlled snow chamber experiment with natural tundra snow collected near Barrow, $\mathrm{AK}$, lend further evidence to this mechanism, and also suggest $\mathrm{Br}_{2}$ production from $\mathrm{OH}$ produced photochemically within the snowpack. This mechanism was further explored in the modeling study of Toyota et al. (2014), which suggested an important role for this activation pathway in producing bromine within the snowpack interstitial air.

Once present in the gas-phase, bromine atoms can be regenerated through radical-radical reactions of $\mathrm{BrO}$ with $\mathrm{XO}$ (where $X=\mathrm{Br}, \mathrm{Cl}$, or iodine: I), $\mathrm{NO}, \mathrm{OH}$, or $\mathrm{CH}_{3} \mathrm{OO}$ to propagate the chain reaction and continue the destruction cycle of ozone. If $\mathrm{BrO}$ photolyzes or reacts with $\mathrm{NO}, \mathrm{O}_{3}$ is regenerated, and there is a null cycle with respect to $\mathrm{O}_{3}$. However, although $\mathrm{O}_{3}$ is not destroyed, these two pathways represent efficient routes for $\mathrm{Br}$ atom propagation. Thus, Reaction (R3) serves to make Reaction (R2) effective in destruction of $\mathrm{O}_{3}$. At the same time, $\mathrm{Br}$ atoms could be recycled through heterogeneous reactions of $\mathrm{HOBr}$ with bromide in the condensed phase to release $\mathrm{Br}_{2}$ to the gas-phase via the now well-known "bromine explosion" mechanism (Vogt et al., 1996; Tang and McConnell, 1996; Fan and Jacob, 1992).

$$
\begin{aligned}
& \mathrm{BrO}+\mathrm{HO}_{2} \rightarrow \mathrm{HOBr}+\mathrm{O}_{2} \\
& \operatorname{HOBr}_{(\mathrm{g})} \rightarrow \mathrm{HOBr}_{(\mathrm{aq})} \\
& \mathrm{HOBr}_{(\mathrm{aq})}+\mathrm{Br}_{(\mathrm{aq})}^{-}+\mathrm{H}_{(\mathrm{aq})}^{+} \leftarrow \rightarrow \mathrm{Br}_{2(\mathrm{aq})}+\mathrm{H}_{2} \mathrm{O} \\
& \mathrm{Br}_{2(\mathrm{aq})} \rightarrow \mathrm{Br}_{2(\mathrm{~g})}
\end{aligned}
$$

Evidence for reaction sequence (R5)-(R8) has been provided through laboratory studies, which found that $\mathrm{Br}_{2}$ was produced when frozen bromide solutions were exposed to gasphase HOBr (Huff and Abbatt, 2002; Adams et al., 2002). This mechanism is believed to proceed rapidly to produce $\mathrm{Br}_{2}$ so long as sufficient bromide is present in an accessible condensed phase. The efficiency of this heterogeneous recycling mechanism has also been found to have a dependence on the acidity of the surface, as was shown using natural environmental snow samples in Pratt et al. (2013) and investigated in the modeling studies of Toyota et al. $(2011,2014)$, in a manner that is consistent with the stoichiometry of Reaction (R7).

To efficiently sustain the ozone destruction cycle to the point of near-complete loss of boundary layer ozone $\left(\left[\mathrm{O}_{3}\right]<2 \mathrm{ppb}\right)$, bromine atoms must be continually recycled through some combination of the above mechanisms. The gas-phase reaction cycle described by Reactions (R1)-(R3) has generally been considered to be the dominant pathway for $\mathrm{Br}$ reformation following the initial activation of $\mathrm{Br}_{2}$ from the surface (the mechanism for which is still not fully understood). Thus, it has been assumed that the rate of ozone destruction can be estimated as Eq. (1) (see Eq. 15 in Hausmann and Platt, 1994, Eq. 3 in Le Bras and Platt, 1995, and Eq. 7 in Zeng et al., 2006) or as Eq. (2), if chlorine chemistry is considered through Reaction (R9) (Eq. IX in Platt and Janssen, 1995).

$$
\begin{aligned}
& \frac{\mathrm{d}\left[\mathrm{O}_{3}\right]}{\mathrm{d} t}=2 \cdot k 3 \cdot[\mathrm{BrO}]^{2} \\
& \frac{\mathrm{d}\left[\mathrm{O}_{3}\right]}{\mathrm{d} t}=2\left(k 3 \cdot[\mathrm{BrO}]^{2}+k 9 \cdot[\mathrm{BrO}] \cdot[\mathrm{ClO}]\right) \\
& \mathrm{BrO}+\mathrm{ClO} \rightarrow \mathrm{Br}+\mathrm{OClO}
\end{aligned}
$$

However, these approximations assume that the ozone destruction rate is dominated by the $\mathrm{BrO}+X \mathrm{O}$ reaction, which in turn necessitates efficient gas-phase recycling of $\mathrm{Br}$; therefore, a relatively long bromine chain length would be required to account for observed rates of ozone destruction. It is, however, possible that $\mathrm{Br}$ atoms are generated mostly by $\mathrm{Br}_{2}$ photolysis, followed by $\mathrm{BrO}$ termination, e.g., by Reaction (R5), in which case a short gas-phase bromine radical chain length would be implied. The chain length for any process depends on the rates of the propagation relative to the production and destruction reactions (Kuo, 1986). It is important to note that, in our definition, the chain length refers to radical propagation reactions occurring solely in the gas phase, and is a quantity completely independent of any condensed-phase chemistry. In the stratosphere, the $\mathrm{Br}-\mathrm{BrO}$ catalytic cycle can have a chain length ranging from $10^{2}$ to $10^{4}$ (Lary, 1996). In the troposphere, there is significantly less solar radiation and many more available sinks; thus, radical chain lengths can be much shorter. For example, the chain length of the tropospheric $\mathrm{HO}_{x}$ cycle has been estimated to be 4-5 (Ehhalt, 1999; Monks, 2005), increasing to 10-20 near the tropopause (Wennberg et al., 1998). The halogen radical chain lengths in the Arctic troposphere have so far not been determined; thus, it is difficult to evaluate whether Eqs. (1) and (2) are appropriate for estimating ozone depletion rates.

The importance of heterogeneous reactions for recycling reactive bromine has been demonstrated in the recent literature (see review by Abbatt et al., 2012). Modeling studies using typical Arctic springtime conditions to simulate ODEs have concluded that ozone depletion cannot be sustained 
without considering the heterogeneous recycling of reactive bromine on snow or aerosol surfaces (e.g., Michalowski et al., 2000; Piot and Von Glasow, 2008; Liao et al., 2012b; Toyota et al., 2014). Michalowski et al. (2000) determined that the rate of ozone depletion in their model was limited by the mass transfer rate of $\mathrm{HOBr}$ to the snowpack (effectively, the rate at which $\mathrm{Br}$ is recycled through the heterogeneous mechanism) and that the depletion of ozone is nearly completely shut down when snowpack interactions are removed. Piot and von Glasow (2008) simulated ozone depletion using the one-dimensional MISTRA model and concluded that major ODEs (defined as complete destruction within 4 days) could only be produced if recycling of deposited bromine on snow is included. Without heterogeneous recycling on the snowpack, the $\mathrm{BrO}_{x}$ termination steps and irreversible loss of $\mathrm{HOBr}$ and $\mathrm{HBr}$ to the surface prohibits the occurrence of an ODE. More recently, using $\mathrm{HOBr}$ observations from Barrow during OASIS (Ocean-Atmosphere-Sea Ice-Snowpack) study, Liao et al. (2012b) found that a simple photochemical model overpredicted observed $\mathrm{HOBr}$ during higher wind events $\left(>6 \mathrm{~m} \mathrm{~s}^{-1}\right.$ ), ostensibly due to an underpredicted heterogeneous loss to aerosol in the model, and concluded that their field observations support the hypothesis of efficient recycling back to reactive bromine via this mechanism.

It is evident that the reactions occurring on snow and aerosol surfaces are likely the initial source of halogen species to the polar boundary layer and that heterogeneous bromine recycling on these surfaces must be considered for $\mathrm{HOBr}$ and $\mathrm{HBr}$ (as well as $\mathrm{BrNO}_{2}$ and $\mathrm{BrONO}_{2}$ in higher $\mathrm{NO}_{x}$ environments). However, the relative importance of gas-phase recycling of bromine atoms is uncertain, even though is it often assumed that the ozone depletion rate can be estimated reasonably well by the catalytic gas-phase radical reaction rates. The goal of this work was to investigate gas-phase $\mathrm{Br}$ atom propagation in terms of the bromine chain length in comparison to the production of $\mathrm{Br}$ atoms through photolysis of $\mathrm{Br}_{2}$ and $\mathrm{BrCl}$, which are predominantly produced directly from surface emissions and/or aerosol release. Here, we present results from our study using a zerodimensional model constrained with time-varying measurements of molecular halogens, $\mathrm{HOBr}, \mathrm{O}_{3}, \mathrm{CO}, \mathrm{NO}, \mathrm{NO}_{2}$, and VOCs (volatile organic compounds) from the 2009 OASIS campaign in Barrow, Alaska. This work builds on the analysis presented in Thompson et al. (2015) using the same model framework. By constraining our model with observations, we were able to conduct an in-depth study of the halogen atom recycling occurring under varying conditions that were observed during the campaign.

\section{Experimental}

\subsection{Measurements and site description}

The analysis presented herein utilizes observations conducted during the OASIS field campaign that occurred during the months of February through April of 2009 in Barrow, AK. The goal of the OASIS study was to investigate the chemical and physical processes occurring within the surface boundary layer during ozone and mercury depletion events in polar spring. This study resulted in the largest suite of simultaneous and co-located atmospheric measurements conducted in the Arctic near-surface atmosphere to date, and represents a unique opportunity for in-depth examination of a multitude of chemical interactions in this environment.

Atmospheric measurements were conducted from instrument trailers located near the Barrow Arctic Research Consortium (BARC) facility on the Naval Arctic Research Laboratory (NARL) campus. Winds arriving at the site are primarily northeasterly, from over the sea ice, and thus represent background conditions with influence from natural processes and snow-air interactions. Winds occasionally shift to westerly, bringing local emissions from the town of Barrow to the site; however, these isolated events are easily identifiable by coincident enhancements in both $\mathrm{NO}_{x}$ and $\mathrm{CO}$.

Measurements of molecular halogens, $\mathrm{HOBr}, \mathrm{NO}, \mathrm{NO}_{2}$, $\mathrm{O}_{3}$, $\mathrm{CO}$, and VOCs were used to constrain the model employed in this analysis. Instrumental methods for these measurements have all been described elsewhere; thus, only a brief description is provided here. Inorganic halogen species $\left(\mathrm{Br}_{2}, \mathrm{Cl}_{2}, \mathrm{BrO}\right.$, and $\mathrm{HOBr}$ ) were measured by chemical ionization mass spectrometry with $\mathrm{I}^{-}$ion chemistry as described in Liao et al. (2011, 2012b, 2014); $\mathrm{O}_{3}, \mathrm{NO}$, and $\mathrm{NO}_{2}$ were measured by chemiluminscence (Ridley et al., 1992; Ryerson et al., 2000). CO was measured using a standard commercial CO analyzer (Thermo Scientific) with infrared absorption detection, and formaldehyde (HCHO) was measured at $1 \mathrm{~Hz}$ frequency using a tunable diode laser absorption spectrometer, as described in Fried et al. (1997) and Lancaster et al. (2000). A large suite of organic compounds was measured in situ by fast GC-MS (Apel et al. 2010) and via whole air canister samples with offline GC-MS (Russo et al., 2010).

\subsection{Model description}

The model used for this study is a zero-dimensional box model developed using the commercial software FACSIMILE. A detailed description of the model can be found in Thompson et al. (2015). We will describe the model only briefly here.

Our model consists of 220 gas-phase reactions and 42 photolysis reactions, representing much of the known gasphase chemistry occurring in the Arctic, including the important halogen, $\mathrm{HO}_{x}, \mathrm{NO}_{x}$, and VOC chemistry associated with ozone depletions. The model also includes an inor- 
ganic iodine reaction scheme adapted from McFiggans et al. (2000, 2002), Calvert and Lindberg (2004), and SaizLopez et al. (2008). Although IO has not been unambiguously measured in the High Arctic above the $\sim 1.5-2 \mathrm{pptv}$ detection limit of LP-DOAS (long-path differential optical absorption spectroscopy), observed enhancements in filterable iodide and total iodine suggest that iodine chemistry is active to some extent in this region (Sturges and Barrie, 1988; Martinez et al., 1999; Mahajan et al., 2010; Hönninger, 2002). Recently, $\mathrm{I}_{2}$ has been detected at tens of pptv within the snowpack interstitial air near Barrow, AK, and at $\leq 0.5 \mathrm{pptv}$ in the near surface air by $\mathrm{I}^{-}$chemical ionization mass spectrometry (CIMS), providing direct evidence supporting the presence of at least low levels of iodine chemistry (Raso et al., 2017). In our previous study (Thompson et al., 2015), we investigated the impact of two different hypothetical levels of iodine. Here, we investigate only the "low iodine" scenario for certain calculations, in which a diurnally varying $I_{2}$ flux is incorporated such that average daytime mixing ratios of IO remain near 1 pptv for the majority of the simulation. These levels of IO are realistic given our current knowledge based on the work of Hönninger (2002) and Raso et al. (2017).

All gas-phase rate constants used in this model were calculated for a temperature of $248 \mathrm{~K}$, consistent with average daytime conditions in Barrow for the period simulated. Although some gas-phase reactions can exhibit a significant temperature dependence, we chose not to incorporate variable temperatures into our model. This is justified in this case because ambient temperature in Barrow for the week of 25 March 2009 varied by less than $10 \mathrm{~K}$ between the maximum and minimum recorded daily temperatures. The radical oxidation and radical-radical reactions that are of primary importance here do not have a large temperature dependence (Atkinson et al., 2006, 2007); for example, a variability of $10 \mathrm{~K}$ imposes an $\sim 1 \%$ change on the rate of ethane oxidation by $\mathrm{Cl}$ atoms and $\mathrm{a}<4 \%$ change on the rate of the $\mathrm{BrO}+\mathrm{BrO}$ radical self-reaction. Most radical-radical reactions have only a small negative-temperature dependence. Furthermore, and as mentioned previously, the major nonradical chemical species driving the model are highly constrained to observations and are not allowed to freely evolve. Table 1 contains an abbreviated list of the reactions included in the model, showing only those reactions that are central to the production, propagation, and termination of bromine radical chemistry, which is the focus of this study. A complete list of reactions can be found in Thompson et al. (2015).

The model is configured to simulate 7 days during late March, 25 through 31 March, that include a period of depleting ozone, a full ozone depletion $\left(\left[\mathrm{O}_{3}\right]<2\right.$ ppbv) lasting for $\sim 3$ days, and recovery. The $\mathrm{O}_{3}$ time series for this period is shown in Fig. 1a, along with radiation as a reference (all plots are in Alaska standard time). We constrain the model to observations for this time period by reading in time-varying data sets of $\mathrm{O}_{3}, \mathrm{C}_{2} \mathrm{H}_{2}, \mathrm{C}_{2} \mathrm{H}_{4}, \mathrm{C}_{2} \mathrm{H}_{6}, \mathrm{C}_{3} \mathrm{H}_{8}, \mathrm{C}_{3} \mathrm{H}_{6}, n-\mathrm{C}_{4} \mathrm{H}_{10}$, $i$ - $\mathrm{C}_{4} \mathrm{H}_{10}, \mathrm{HCHO}, \mathrm{CH}_{3} \mathrm{CHO}, \mathrm{CH}_{3} \mathrm{COCH}_{3}$, methyl ethyl ketone (MEK), $\mathrm{Cl}_{2}, \mathrm{Br}_{2}, \mathrm{HOBr}, \mathrm{NO}, \mathrm{NO}_{2}$, and $\mathrm{CO}$ at $10 \mathrm{~min}$ time steps. All other gas-phase species are allowed to freely evolve. Surface fluxes (represented as volumetric fluxes) are used for $\mathrm{HONO}$ and $\mathrm{I}_{2}$ and are scaled to $J\left(\mathrm{NO}_{2}\right)$ as a proxy for radiation as both of these species are likely to be produced photochemically. Further discussion regarding HONO can be found in Thompson et al. (2015).

Photolysis rate constants ( $J$ coefficients) for many of the species included were calculated during OASIS using the Tropospheric Ultraviolet and Visible Radiation model from measurements of down-welling actinic flux conducted throughout the campaign (Shetter and Müller, 1999; Stephens et al., 2012). Estimates of $J_{\max }$ in the Arctic for $\mathrm{OClO}$ were taken from Pöhler et al. (2010), for $\mathrm{HOCl}$ from Lehrer et al. (2004), and for $\mathrm{CHBr}_{3}$ from Papanastasiou et al. (2014). $J_{\max }$ values for the iodine compounds were calculated according the work of Calvert and Lindberg (2004), which also simulated conditions for late March in Barrow, Alaska. Time-varying $J$ coefficients for $\mathrm{O}_{3}$ and $\mathrm{NO}_{2}$ were read into the model at $10 \mathrm{~min}$ time steps. All other photolysis reactions were scaled to $J\left(\mathrm{NO}_{2}\right)$ in the modeling code using the maximum $J$ coefficients $\left(J_{\max }\right)$ for 25 March (a clear-sky day) as a basis for scaling. For cloudy days, this method assumes that $J$ coefficients for other photolytically active species are attenuated in a manner that is proportional to $J\left(\mathrm{NO}_{2}\right)$.

In the initial development of the model, heterogeneous reactions of halogen species occurring on aerosol and snowpack surfaces were included, as well as mass transfer and dry deposition for certain species using the method and mechanism of Michalowksi et al. (2000). This mechanism assumes aqueous-phase kinetics for those reactions occurring within a uniformly distributed quasi-liquid layer (QLL), in a similar fashion as numerous other models (e.g., Piot and von Glasow, 2008; Thomas et al., 2011; Toyota et al., 2014). It was originally intended to utilize this multiphase chemistry to produce halogen radical precursors. However, the heterogeneous production mechanisms could not reproduce observed $\mathrm{Br}_{2}$ or $\mathrm{Cl}_{2}$ from OASIS. This reflects the complex but not fully understood condensed-phase chemistry and physics that lead to the production of $\mathrm{Br}_{2}$ (and $\mathrm{Cl}_{2}$ ) $(\mathrm{Abbatt}$ et al., 2012; Domine et al., 2013; Pratt et al., 2013). Additionally, the current knowledge of the physical properties of the QLL and the location of liquid-like surfaces on snow grains would seem to invalidate the aforementioned assumptions on which many of the current heterogeneous models are based (Domine et al., 2013), specifically that the chemistry occurs in a liquid-like environment on snow grains. Indeed, Cao et al. (2014) adopted a simplified heterogeneous chemistry mechanism in their modeling of Arctic ozone depletion, wherein they use the mass transfer of $\mathrm{HOBr}$ to the surface as the rate-limiting step in $\mathrm{Br}_{2}$ production, citing the lack of suitable reaction mechanisms with which to properly simulate condensed-phase chemistry on snow/ice. Ad- 
Table 1. Reactions used in the model that are pertinent to bromine chemistry. All rate constants (with the exception of photolysis $J$ coefficients) are in units of $\mathrm{cm}^{3}$ molecule $\mathrm{s}^{-1} \mathrm{~s}^{-1}$.

\begin{tabular}{|c|c|c|c|}
\hline Gas-phase reactions & Rate constant & & Reference \\
\hline $\mathrm{Br}+\mathrm{O}_{3} \rightarrow \mathrm{BrO}$ & $6.75 \times 10^{-13}$ & & Atkinson et al. (2004) \\
\hline $\mathrm{Br}+\mathrm{C}_{2} \mathrm{H}_{4} \rightarrow \mathrm{HBr}+\mathrm{C}_{2} \mathrm{H}_{5} \mathrm{OO}$ & $1.3 \times 10^{-13}$ & & Atkinson et al. (2004) \\
\hline $\mathrm{Br}+\mathrm{C}_{3} \mathrm{H}_{6} \rightarrow \mathrm{HBr}+\mathrm{C}_{3} \mathrm{H}_{5}$ & $1.60 \times 10^{-12}$ & & Atkinson et al. (2004) \\
\hline $\mathrm{Br}+\mathrm{HCHO} \rightarrow \mathrm{HBr}+\mathrm{CO}+\mathrm{HO}_{2}$ & $6.75 \times 10^{-13}$ & & Sander et al. (2006) \\
\hline $\mathrm{Br}+\mathrm{CH}_{3} \mathrm{CHO} \rightarrow \mathrm{HBr}+\mathrm{CH}_{3} \mathrm{COOO}$ & $2.8 \times 10^{-12}$ & & Atkinson et al. (2004) \\
\hline $\mathrm{Br}+\mathrm{C}_{3} \mathrm{H}_{6} \mathrm{O} \rightarrow \mathrm{HBr}$ & $9.7 \times 10^{-12}$ & & Wallington et al. (1989) \\
\hline $\mathrm{Br}+\mathrm{nButanal} \rightarrow \mathrm{HBr}$ & $9.7 \times 10^{-12}$ & & estimate from Michalowski et al. (2000) \\
\hline $\mathrm{Br}+\mathrm{CH}_{3} \mathrm{OOH} \rightarrow \mathrm{HBr}+\mathrm{CH}_{3} \mathrm{OO}$ & $4.03 \times 10^{-15}$ & & Mallard et al. (1993) \\
\hline $\mathrm{Br}+\mathrm{NO}_{2} \rightarrow \mathrm{BrNO}_{2}$ & $2.7 \times 10^{-11}$ & & Atkinson et al. (2004) \\
\hline $\mathrm{Br}+\mathrm{BrNO}_{3} \rightarrow \mathrm{Br}_{2}+\mathrm{NO}_{3}$ & $4.9 \times 10^{-11}$ & & Orlando and Tyndall (1996) \\
\hline $\mathrm{Br}+\mathrm{OClO} \rightarrow \mathrm{BrO}+\mathrm{ClO}$ & $1.43 \times 10^{-13}$ & & Atkinson et al. (2004) \\
\hline $\mathrm{BrO}+\mathrm{O}\left({ }^{3} \mathrm{P}\right) \rightarrow \mathrm{Br}$ & $4.8 \times 10^{-11}$ & & Atkinson et al. (2004) \\
\hline $\mathrm{BrO}+\mathrm{OH} \rightarrow \mathrm{Br}+\mathrm{HO}_{2}$ & $4.93 \times 10^{-11}$ & & Atkinson et al. (2004) \\
\hline $\mathrm{BrO}+\mathrm{HO}_{2} \rightarrow \mathrm{HOBr}$ & $3.38 \times 10^{-11}$ & & Atkinson et al. (2004) \\
\hline $\mathrm{BrO}+\mathrm{CH}_{3} \mathrm{OO} \rightarrow \mathrm{HOBr}+\mathrm{CH}_{2} \mathrm{OO}$ & $4.1 \times 10^{-12}$ & & Aranda et al. (1997) \\
\hline $\mathrm{BrO}+\mathrm{CH}_{3} \mathrm{OO} \rightarrow \mathrm{Br}+\mathrm{HCHO}+\mathrm{HO}_{2}$ & $1.6 \times 10^{-12}$ & & Aranda et al. (1997) \\
\hline $\mathrm{BrO}+\mathrm{CH}_{3} \mathrm{COOO} \rightarrow \mathrm{Br}+\mathrm{CH}_{3} \mathrm{COO}$ & $1.7 \times 10^{-12}$ & & estimate from Michalowski et al. (2000) \\
\hline $\mathrm{BrO}+\mathrm{C}_{3} \mathrm{H}_{6} \mathrm{O} \rightarrow \mathrm{HOBr}$ & $1.5 \times 10^{-14}$ & & estimate from Michalowski et al. (2000) \\
\hline $\mathrm{BrO}+\mathrm{NO} \rightarrow \mathrm{Br}+\mathrm{NO}_{2}$ & $2.48 \times 10^{-11}$ & & Atkinson et al. (2004) \\
\hline $\mathrm{BrO}+\mathrm{NO}_{2} \rightarrow \mathrm{BrNO}_{3}$ & $1.53 \times 10^{-11}$ & & Atkinson et al. (2004) \\
\hline $\mathrm{BrO}+\mathrm{BrO} \rightarrow \mathrm{Br}+\mathrm{Br}$ & $2.82 \times 10^{-12}$ & & Sander et al. (2006) \\
\hline $\mathrm{BrO}+\mathrm{BrO} \rightarrow \mathrm{Br}_{2}$ & $9.3 \times 10^{-13}$ & & Sander et al. (2006) \\
\hline $\mathrm{BrO}+\mathrm{HBr} \rightarrow \mathrm{HOBr}+\mathrm{Br}$ & $2.1 \times 10^{-14}$ & & Hansen et al. (1999) \\
\hline $\mathrm{HBr}+\mathrm{OH} \rightarrow \mathrm{Br}+\mathrm{H}_{2} \mathrm{O}$ & $1.26 \times 10^{-11}$ & & Sander et al. (2006) \\
\hline $\mathrm{CH}_{3} \mathrm{Br}+\mathrm{OH} \rightarrow \mathrm{H}_{2} \mathrm{O}+\mathrm{Br}$ & $1.27 \times 10^{-14}$ & & Atkinson et al. (2004) \\
\hline $\mathrm{CHBr}_{3}+\mathrm{OH} \rightarrow \mathrm{H}_{2} \mathrm{O}+\mathrm{Br}$ & $1.2 \times 10^{-13}$ & & Atkinson et al. (2004) \\
\hline $\mathrm{Cl}+\mathrm{BrCl} \leftarrow \rightarrow \mathrm{Br}+\mathrm{Cl}_{2}$ & $f: 1.5 \times 10^{-11} r: 1.1 \times 10^{-15}$ & & Clyne et al. (1972) \\
\hline $\mathrm{Cl}+\mathrm{Br}_{2} \leftarrow \rightarrow \mathrm{BrCl}+\mathrm{Br}$ & $f: 1.2 \times 10^{-10} r: 3.3 \times 10^{-15}$ & & Clyne et al. (1972) \\
\hline $\mathrm{BrO}+\mathrm{ClO} \rightarrow \mathrm{Br}+\mathrm{Cl}$ & $7.04 \times 10^{-12}$ & & Atkinson et al. (2004) \\
\hline $\mathrm{BrO}+\mathrm{ClO} \rightarrow \mathrm{BrCl}$ & $1.15 \times 10^{-12}$ & & Atkinson et al. (2004) \\
\hline $\mathrm{BrO}+\mathrm{ClO} \rightarrow \mathrm{Br}+\mathrm{OClO}$ & $9.06 \times 10^{-12}$ & & Atkinson et al. (2004) \\
\hline $\mathrm{HOBr}+\mathrm{OH} \rightarrow \mathrm{BrO}+\mathrm{H}_{2} \mathrm{O}$ & $5.0 \times 10^{-13}$ & & Kukui et al. (1996) \\
\hline $\mathrm{HOBr}+\mathrm{Cl} \rightarrow \mathrm{BrCl}+\mathrm{OH}$ & $8.0 \times 10^{-11}$ & & Kukui et al. (1996) \\
\hline $\mathrm{HOBr}+\mathrm{O}\left({ }^{3} \mathrm{P}\right) \rightarrow \mathrm{BrO}+\mathrm{OH}$ & $2.12 \times 10^{-11}$ & & Atkinson et al. (2004) \\
\hline $\mathrm{IO}+\mathrm{BrO} \rightarrow \mathrm{Br}+\mathrm{OIO}$ & $9.36 \times 10^{-11}$ & & Atkinson et al. (2004) \\
\hline $\mathrm{IO}+\mathrm{BrO} \rightarrow \mathrm{IBr}$ & $4.32 \times 10^{-11}$ & & Atkinson et al. (2004) \\
\hline $\mathrm{IO}+\mathrm{BrO} \rightarrow \mathrm{Br}+\mathrm{I}$ & $7.2 \times 10^{-12}$ & & Atkinson et al. (2004) \\
\hline Photolysis reactions & $J_{\max }(25 \mathrm{March}) \mathrm{s}^{-1}$ & Lifetime & Reference \\
\hline $\mathrm{BrNO}_{3} \rightarrow \mathrm{Br}+\mathrm{NO}_{3}$ & $2.1 \times 10^{-4}$ & $1.3 \mathrm{~h}$ & calculated from OASIS data \\
\hline $\mathrm{BrNO}_{3} \rightarrow \mathrm{BrO}+\mathrm{NO}_{2}$ & $1.2 \times 10^{-3}$ & $14.2 \mathrm{~min}$ & calculated from OASIS data \\
\hline $\mathrm{BrO} \rightarrow \mathrm{Br}+\mathrm{O}\left({ }^{3} \mathrm{P}\right)$ & $3.0 \times 10^{-2}$ & $33 \mathrm{~s}$ & calculated from OASIS data \\
\hline $\mathrm{Br}_{2} \rightarrow \mathrm{Br}+\mathrm{Br}$ & $4.4 \times 10^{-2}$ & $23 s$ & calculated from OASIS data \\
\hline $\mathrm{HOBr} \rightarrow \mathrm{Br}+\mathrm{OH}$ & $2.3 \times 10^{-3}$ & $7.2 \mathrm{~min}$ & calculated from OASIS data \\
\hline $\mathrm{BrNO}_{2} \rightarrow \mathrm{Br}+\mathrm{NO}_{2}$ & $1.5 \times 10^{-4}$ & $1.8 \mathrm{~h}$ & estimate from Lehrer et al. (2004) \\
\hline $\mathrm{BrCl} \rightarrow \mathrm{Br}+\mathrm{Cl}$ & $1.26 \times 10^{-2}$ & $1.3 \mathrm{~min}$ & calculated from OASIS data \\
\hline
\end{tabular}


Table 1. Continued.

\begin{tabular}{|c|c|c|c|}
\hline Mass transfer reactions & $k_{t}($ forward $)$ & $k_{t}$ (reverse) & \\
\hline $\mathrm{HBr}_{(\mathrm{g})} \rightarrow \mathrm{H}_{(\mathrm{p})}^{+}+\mathrm{Br}_{(\mathrm{p})}^{-}$ & $1.80 \times 10^{-3}$ & & \\
\hline $\mathrm{HCl}_{(\mathrm{g})} \rightarrow \mathrm{H}_{(\mathrm{p})}^{+}+\mathrm{Cl}_{(\mathrm{p})}^{-}$ & $2.58 \times 10^{-3}$ & & \\
\hline $\operatorname{HOBr}_{(\mathrm{g})} \rightarrow \operatorname{HOBr}_{(\mathrm{p})}$ & $1.26 \times 10^{-3}$ & & \\
\hline $\mathrm{BrNO}_{2(\mathrm{~g})} \rightarrow \mathrm{BrNO}_{2(\mathrm{p})}$ & $1.26 \times 10^{-3}$ & & \\
\hline $\mathrm{BrONO}_{3(\mathrm{~g})} \rightarrow \mathrm{BrONO}_{3(\mathrm{p})}$ & $1.26 \times 10^{-3}$ & & \\
\hline $\mathrm{Br}_{2(\mathrm{~g})} \longleftrightarrow \mathrm{Br}_{2(\mathrm{p})}$ & $1.78 \times 10^{-5}$ & $2.97 \times 10^{8}$ & \\
\hline $\mathrm{BrCl}_{(\mathrm{g})} \leftarrow \rightarrow \mathrm{BrCl}_{(\mathrm{p})}$ & $6.60 \times 10^{-4}$ & $1.91 \times 10^{10}$ & \\
\hline $\operatorname{IBr}_{(\mathrm{p})} \rightarrow \operatorname{IBr}_{(\mathrm{g})}$ & $5.53 \times 10^{9}$ & & \\
\hline $\mathrm{HBr}_{(\mathrm{g})} \rightarrow \mathrm{H}_{(\mathrm{s})}^{+}+\mathrm{Br}_{(\mathrm{s})}^{-}$ & $1.67 \times 10^{-5}$ & & \\
\hline $\mathrm{HCl}_{(\mathrm{g})} \rightarrow \mathrm{H}_{(\mathrm{s})}^{+}+\mathrm{Cl}_{(\mathrm{s})}^{-}$ & $1.67 \times 10^{-5}$ & & \\
\hline $\operatorname{HOBr}_{(\mathrm{g})} \rightarrow \operatorname{HOBr}_{(\mathrm{s})}$ & $1.67 \times 10^{-5}$ & & \\
\hline $\mathrm{BrNO}_{2(\mathrm{~g})} \rightarrow \mathrm{BrNO}_{2(\mathrm{~s})}$ & $1.67 \times 10^{-4}$ & & \\
\hline $\mathrm{BrONO}_{3(\mathrm{~g})} \rightarrow \mathrm{BrONO}_{3(\mathrm{~s})}$ & $1.26 \times 10^{-4}$ & & \\
\hline $\mathrm{Br}_{2(\mathrm{~g})} \longleftrightarrow \mathrm{Br}_{2(\mathrm{~s})}$ & $1.0 \times 10^{-5}$ & $7.71 \times 10^{-2}$ & \\
\hline $\mathrm{BrCl}_{(\mathrm{g})} \leftarrow \rightarrow \mathrm{BrCl}_{(\mathrm{s})}$ & $1.25 \times 10^{-5}$ & $7.71 \times 10^{-2}$ & \\
\hline $\operatorname{IBr}_{(\mathrm{s})} \rightarrow \mathrm{IBr}_{(\mathrm{g})}$ & $7.71 \times 10^{-2}$ & & \\
\hline Aqueous-phase reactions & $k$ (particle) & $k$ (snow) & Reference \\
\hline $\mathrm{Cl}^{-}+\mathrm{HOBr}+\mathrm{H}^{+} \rightarrow \mathrm{BrCl}$ & $5.17 \times 10^{-21}$ & $9.30 \times 10^{-26}$ & Wang et al. (1994) \\
\hline $\mathrm{Br}^{-}+\mathrm{HOCl}+\mathrm{H}^{+} \rightarrow \mathrm{BrCl}$ & $1.2 \times 10^{-24}$ & $2.15 \times 10^{-29}$ & Sander et al. (1997) \\
\hline $\mathrm{Br}^{-}+\mathrm{HOBr}+\mathrm{H}^{+} \rightarrow \mathrm{Br}_{2}$ & $1.47 \times 10^{-20}$ & $2.64 \times 10^{-25}$ & Beckwith et al. (1996) \\
\hline $\mathrm{Br}^{-}+\mathrm{HOI}+\mathrm{H}^{+} \rightarrow \mathrm{IBr}$ & $3.04 \times 10^{-18}$ & $5.46 \times 10^{-23}$ & Troy et al. (1991) \\
\hline $\mathrm{BrCl}+\mathrm{Cl}^{-} \rightarrow \mathrm{BrCl}_{2}^{-}$ & 3.3 & $5.99 \times 10^{-5}$ & Michalowski et al. (2000) \\
\hline $\mathrm{BrCl}_{2}^{-} \rightarrow \mathrm{BrCl}+\mathrm{Cl}^{-}$ & $1.58 \times 10^{9}$ & $1.58 \times 10^{9}$ & Michalowski et al. (2000) \\
\hline $\mathrm{BrCl}+\mathrm{Br}^{-} \rightarrow \mathrm{Br}_{2} \mathrm{Cl}^{-}$ & 3.3 & $5.99 \times 10^{-5}$ & Michalowski et al. (2000) \\
\hline $\mathrm{Br}_{2} \mathrm{Cl}^{-} \rightarrow \mathrm{BrCl}+\mathrm{Br}^{-}$ & $3.34 \times 10^{5}$ & $3.34 \times 10^{5}$ & Wang et al. (1994) \\
\hline $\mathrm{Cl}_{2}+\mathrm{Br}^{-} \rightarrow \mathrm{BrCl}_{2}^{-}$ & 4.27 & $7.66 \times 10^{-5}$ & Wang et al. (1994) \\
\hline $\mathrm{BrCl}_{2}^{-} \rightarrow \mathrm{Cl}_{2}+\mathrm{Br}^{-}$ & $6.94 \times 10^{2}$ & $6.94 \times 10^{2}$ & Wang et al. (1994) \\
\hline $\mathrm{O}_{3}+\mathrm{Br}^{-} \rightarrow \mathrm{HOBr}$ & $4.5 \times 10^{-9}$ & $8.08 \times 10^{-14}$ & Oum et al. (1998) \\
\hline
\end{tabular}

mittedly, our model is also not able to capture these complex heterogeneous processes. However, as discussed thoroughly by Domine et al. (2013), even our most complex state-of-theart snow chemistry models are neither physically nor chemically accurate, and rely upon a variety of adjustable parameters to produce reasonable results, because of the lack of fundamental understanding of the actual phase and physical and chemical environment in which the chemistry is occurring. It is thus clear that the kinetics of the individual reactions in such a case cannot be reliably simulated.

In light of the limitations of all models of cryosphere photochemistry, a strength of this study, and opportunity, rests with the fact that we have observations of key halogen species, including $\mathrm{Br}_{2}, \mathrm{Cl}_{2}, \mathrm{BrO}, \mathrm{ClO}, \mathrm{HOBr}$, as well as VOCs, $\mathrm{NO}_{x}, \mathrm{OH}$, and $\mathrm{HO}_{2}$. Therefore, to study the gasphase recycling discussed in the Introduction, in this work $\mathrm{Br}_{2}$ and $\mathrm{Cl}_{2}$ concentrations were fixed at the observed levels (see Thompson et al., 2015, for further discussion) and were not produced via heterogeneous chemistry. During a period spanning a portion of 29 and $30 \mathrm{March}, \mathrm{Br}_{2}$ observa- tions are not available due to instrument instability. Here, we have filled in the missing portion of data with average daytime $\mathrm{Br}_{2}$ values based on observations from 27 and 28 March and the morning data available for 29 March, and use average nighttime values for the night of 29/30 March using the observations from the two adjacent nighttime periods. The filled-in values for $\mathrm{Br}_{2}$ result in reasonable agreement between modeled and observed $\mathrm{BrO}$ for this period. In the analyses presented in Figs. 3 and 5-10 we have indicated this period of missing and filled-in $\mathrm{Br}_{2}$ values with a shaded box. Due to the sparseness of $\mathrm{BrCl}$ observations during OASIS, only daytime $\mathrm{BrCl}$ was used as produced in the model multiphase mechanism. While we do not argue that the production mechanism for $\mathrm{BrCl}$ is accurate, the daytime simulated $\mathrm{BrCl}$ mixing ratios of $0-10 \mathrm{pptv}$ are in approximate agreement with the available data for the campaign. In any case, according to our model, $\mathrm{BrCl}$ was not a significant source of either $\mathrm{Br}$ or $\mathrm{Cl}$ atoms relative to $\mathrm{Br}_{2}$ and $\mathrm{Cl}_{2}$.

Though we do not use the heterogeneous chemistry module for any chemical production (other than $\mathrm{BrCl}$ ), deposi- 
tion and mass transfer is a significant and critical sink for certain species. Thus, we do make use of this aspect of the multiphase portion of the model, as described below. The dry deposition velocity of $\mathrm{O}_{3}$ to the snowpack is estimated at $0.05 \mathrm{~cm} \mathrm{~s}^{-1}$, consistent with previous measurements and modeling studies (Gong et al., 1997; Michalowski et al., 2000; Helmig et al., 2007; Cavender et al., 2008), though it is recognized that there is large uncertainty with this parameter from field observations (Helmig et al., 2007, 2012). Assuming a boundary layer height of $300 \mathrm{~m}$, this corresponds to a transfer coefficient, $k_{\mathrm{t}}$, of $1.67 \times 10^{-6} \mathrm{~s}^{-1}$. Though we have incorporated the deposition of $\mathrm{O}_{3}$ in the model, the gas-phase mixing ratio of $\mathrm{O}_{3}$ is constrained to observations, which adjusts on 10 min time steps. Dry deposition velocities for the stable Arctic environment have not been determined for the halogen acids ( $\mathrm{HBr}, \mathrm{HCl}, \mathrm{HOBr}, \mathrm{HOCl}, \mathrm{HOI}$ ); therefore, we use the estimation method of Michalowski et al. (2000) and assume a deposition velocity that is 10 times greater than for $\mathrm{O}_{3}$, leading to a $k_{\mathrm{t}}$ of $1.67 \times 10^{-5} \mathrm{~s}^{-1}$. In most model runs, we have chosen to constrain to $\mathrm{HOBr}$ observations (further described in Sect. 3.1), and thus a similar situation exists as for $\mathrm{O}_{3}$ mentioned above. We assume an equivalent $k_{t}$ for the oxidized nitrogen compounds $\left(\mathrm{HNO}_{3}, \mathrm{HO}_{2} \mathrm{NO}_{2}, \mathrm{HONO}, \mathrm{N}_{2} \mathrm{O}_{5}\right.$, $\mathrm{BrNO}_{2}$, and $\mathrm{BrONO}_{2}$ ). The mass transfer coefficient of atmospheric species to the particle phase is calculated as a firstorder process as described in Jacob (2000). The concentration of aerosol surface area used was $3.95 \times 10^{-7} \mathrm{~cm}^{2} \mathrm{~cm}^{-3}$ as calculated by Michalowski et al. (2000) from measurements made at Alert by Staebler et al. (1994), with a maximum aerosol radius of $r=0.1 \mu \mathrm{m}$. These levels are also consistent with observations of aerosol surface area at Barrow, which ranged between $9 \times 10^{-8}$ and $40 \times 10^{-7} \mathrm{~cm}^{2} \mathrm{~cm}^{-3}$ (Liao et al., 2012b). We recognize that this constant level of aerosols imparts a constant loss rate in the model and does not take into account any variability in the uptake strength. Because many of these species are lacking empirically derived deposition velocities (e.g., $\mathrm{HOBr}$ ), there is necessarily large uncertainty in these values, and it is not possible at this time to ascertain whether the uncertainty associated with the deposition velocity estimation is greater or less than the uncertainty imposed by using a constant aerosol surface area. Liao et al. (2012b) did use time-varying aerosol surface area from observations at Barrow; however, they suggested that simple parameterization of deposition of $\mathrm{HOBr}$ to aerosols was insufficient for accurately simulating $\mathrm{HOBr}$ (further discussion of $\mathrm{HOBr}$ is in Sect. 3.1). Given the highly simplified nature of the surface deposition in our model, we do not attempt to differentiate between aerosol uptake and deposition to the snow surface, and instead we lump these two terms together under the "surface deposition" umbrella. However, while we mostly constrain the model to observed $\mathrm{HOBr}$, the comparison to simulated $\mathrm{HOBr}$ using these values is instructive.
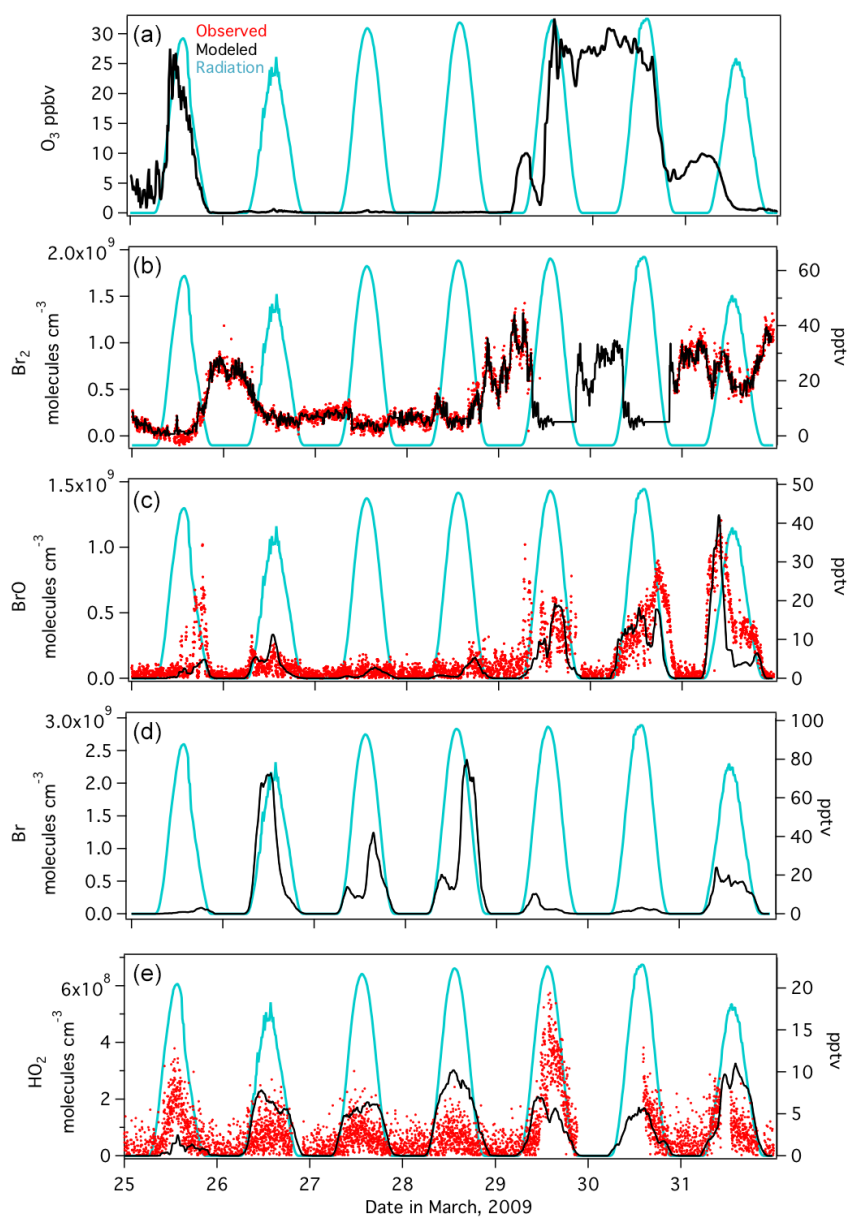

Figure 1. Time series of gas-phase concentrations and mixing ratios of $\mathrm{O}_{3}, \mathrm{Br}_{2}, \mathrm{BrO}, \mathrm{Br}$, and $\mathrm{HO}_{2}$ in the model (black trace) for the 7-day period simulated. Observations are plotted in red where available for $\mathrm{Br}_{2}, \mathrm{BrO}$, and $\mathrm{HO}_{2} . \mathrm{O}_{3}$ and $\mathrm{Br}_{2}$ are constrained species in the model. Simulated output of $\mathrm{BrO}, \mathrm{Br}$, and $\mathrm{HO}_{2}$ are smoothed by hourly averaging. Radiation is shown as the cyan trace as a reference. Time is expressed in Alaska standard time.

\section{Results and discussion}

\subsection{Comparison of modeled and observed $\mathrm{Br}_{2}, \mathrm{BrO}$, $\mathrm{HOBr}$, and $\mathrm{HO}_{2}$}

This work focuses on the propagation and production mechanisms of $\mathrm{Br}$ atoms, and thus it is critical that our model accurately captures $\mathrm{BrO}$ and $\mathrm{Br}_{2}$ at mixing ratios that are consistent with observations. Figure $1 \mathrm{~b}$ and $\mathrm{c}$ show comparisons between modeled mixing ratios (black trace) of $\mathrm{Br}_{2}$ and $\mathrm{BrO}$ compared to the measured values during this time (red data) by CIMS (Liao et al., 2012b). Modeled BrO is presented as hourly averages. In the model, $\mathrm{Br}_{2}$ is fixed to time-varying observations, whereas $\mathrm{BrO}$ is produced strictly through the gas-phase photochemical reactions. The model captures the overall temporal profile and magnitude of $\mathrm{BrO}$ throughout the period. It should be noted, however, that the uncertainty 
in the $\mathrm{BrO}$ measurements is large during ODEs as the observed values are very near the limit of detection (LOD of $\sim 2$ pptv with uncertainty of $-3 /+1$ pptv near the LOD).

$\mathrm{Br}_{2}$ mixing ratios reach 2-12 pptv (Fig. 1b) during the daytime. Given the short lifetime of $\mathrm{Br}_{2}$ resulting from rapid photolysis, these daytime mixing ratios imply a large surface flux, that in turn produces the $\mathrm{BrO}$ mixing ratios observed. These $\mathrm{Br}_{2}$ levels are consistent with previous Arctic measurements that observed daytime $\mathrm{Br}_{2}$ up to $27 \mathrm{pptv}$ (Foster et al., 2001) and agree well with the "uncorrected" $\mathrm{Br}_{2}$ data reported in Liao et al. (2012a, b) for this period. It has been suggested that daytime $\mathrm{Br}_{2}$ greater than the CIMS instrumental detection limit ( $\sim 1$ pptv) is an artifact of $\mathrm{HOBr}$ conversion to $\mathrm{Br}_{2}$ on the instrument using an aircraft inlet (Neuman et al., 2010); however, for the instrument configuration employed during OASIS, it is not clear how much, if any, of the $\mathrm{Br}_{2}$ signal is a result of $\mathrm{HOBr}$ reactions on instrument surfaces.

An estimate of the effective mixing height of $\mathrm{Br}_{2}$ can be calculated using the method of Guimbaud et al. (2002) and using an average measured diffusivity during OASIS of $1500 \mathrm{~cm}^{2} \mathrm{~s}^{-1}$ (R. Staebler, personal communication, 2015). By assuming that photolysis is the dominant loss mechanism controlling the $\mathrm{Br}_{2}$ midday lifetime in a stable boundary layer typical of Arctic conditions, the daytime effective mixing height is $\sim 1.85 \mathrm{~m}$. This also assumes that the snowpack is the primary source of $\mathrm{Br}_{2}$ emissions, which is consistent with previous assumptions for the aldehydes (Sumner and Shepson, 1999; Guimbaud et al., 2002) and is supported by direct empirical evidence of the tundra snowpack being a relatively strong source of $\mathrm{Br}_{2}$ (Pratt et al., 2013). Enhanced $\mathrm{Br}_{2}$ within the snowpack interstitial air has also been predicted from the modeling studies of Toyota et al. (2011, 2014). From this estimation, a significant fraction of the $\mathrm{Br}_{2}$ present at the surface would remain at the height of the instrument inlet $(\sim 1 \mathrm{~m})$ in the sunlit periods. If aerosols do represent a significant source of $\mathrm{Br}_{2}$ as has been hypothesized, and inferred indirectly from bromide depletion in sea salt aerosols (Sander et al., 2003), then one would expect enhanced $\mathrm{Br}_{2}$ to be present throughout the height of the boundary layer. In our highly constrained model, daytime $\mathrm{Br}_{2}$ mixing ratios greater than 1 pptv are necessary to reproduce observed $\mathrm{BrO}$; therefore, this modeling study suggests that $\mathrm{Br}_{2}$ should indeed be present and above the instrument detection limit during the daytime. $\mathrm{Br}$ atoms are predicted at concentrations ranging from $1 \times 10^{7}$ to $3 \times 10^{9}$ molecules $\mathrm{cm}^{-3}$. The hourly averaged model output for $\mathrm{Br}$ is shown in Fig. 1d. No direct measurements of $\mathrm{Br}$ atoms are available with which to compare, though these values are within the range of estimates determined by Jobson et al. (1994) and Ariya et al. (1998).

In the case of $\mathrm{HOBr}$, our model originally simulated this species based on the known gas-phase sources and sinks (including photolysis) and deposition/uptake to surfaces as described above. As shown in Thompson et al. (2015), and again in Fig. 2a, given the observed $\mathrm{Br}_{2}$ mixing ratios, the
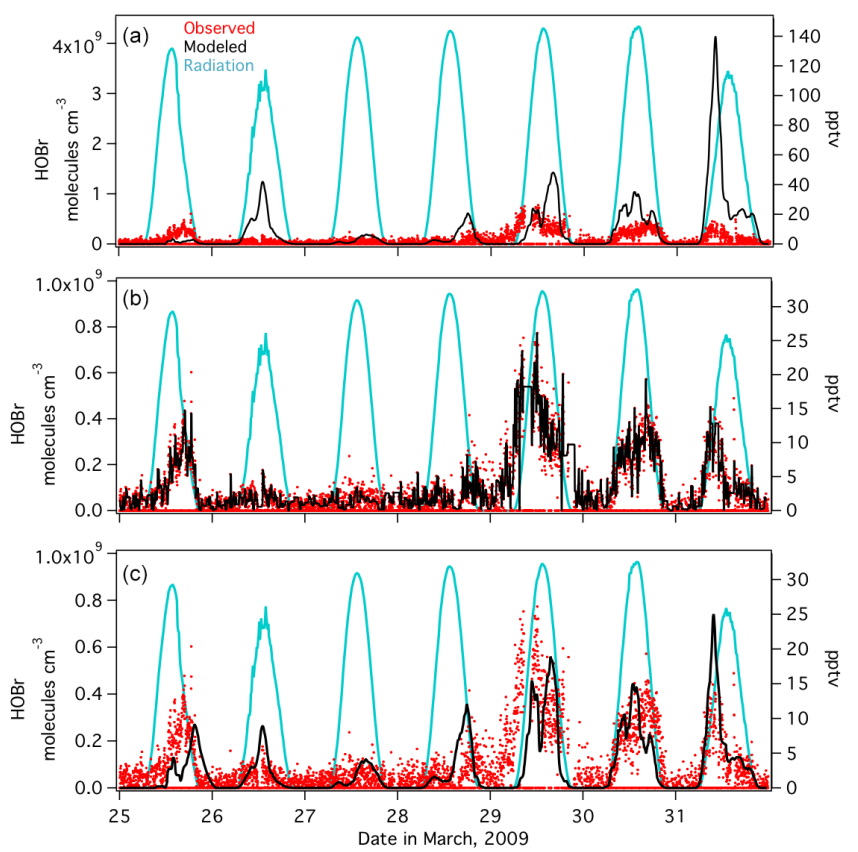

Figure 2. Simulated (black trace) versus observed (red markers) $\mathrm{HOBr}$ mixing ratios shown for three different versions of the model: (a) $\mathrm{HOBr}$ unconstrained and allowed to freely evolve with a constant surface deposition term as described in the Methods, (b) $\mathrm{HOBr}$ constrained to observations, (c) $\mathrm{HOBr}$ unconstrained but with a variable surface deposition that is enhanced during higher wind speeds. Simulated (unconstrained) output in (a, c) are smoothed by hourly averaging. Radiation is shown as the cyan trace as a reference. Time is expressed in Alaska standard time.

model greatly overestimated HOBr. Liao et al. (2012b) simulated inorganic bromine species from the OASIS campaign using a simple steady-state model and experienced that their model also overestimated the observed $\mathrm{HOBr}$, with the overestimation becoming especially pronounced during periods of higher winds. They suggested a faster heterogeneous loss to aerosols or blowing snow that was not represented in their model, despite utilizing time-varying aerosol surface area from observations. For the majority of the results presented in this work, we chose to operate our model constrained to $\mathrm{HOBr}$ observations, as illustrated in Fig. 2b. Figure 2c shows modeled $\mathrm{HOBr}$ obtained by adjusting the deposition to aerosols based on daily wind speeds (resulting in $k_{t}$ values ranging from $1 \times 10^{-2}$ to $1.5 \times 10^{-4} \mathrm{~s}^{-1}$ ), and tuned to provide reasonable agreement with observations. This resulted in smaller deposition rates on 25 through 27 March when winds were calm, and higher deposition rates on 29 through 31 March when winds were up to $9 \mathrm{~m} \mathrm{~s}^{-1}$. This method allowed us to calculate the importance of surface deposition of $\mathrm{HOBr}$ relative to photolysis as a sink for this compound, but the constrained version of the model was used for all other calculations, e.g., for the chain length calculations. 
$\mathrm{HO}_{2}$ is essential for the heterogeneous recycling of bromine (via Reactions R5-R7). Therefore, it is important that our model provides a reasonable estimation of $\mathrm{HO}_{2}$ for this analysis. In Fig. 1e we show a comparison of simulated, hourly averaged $\mathrm{HO}_{2}$ (black trace) and observed $\mathrm{HO}_{2}$ from OASIS for this period (red data), measured using a CIMS developed for peroxy radicals (Edwards et al., 2003). The range of daytime $\mathrm{HO}_{2}$ mixing ratios is reproduced reasonably well. Simulated $\mathrm{HO}_{2}$ is on the lower limit of observations for 25 and 29 March, and does not reach the maximum mixing ratios observed. The model also somewhat overpredicts $\mathrm{HO}_{2}$ on 28 through 30 March; however, the model values are within the stated $25-100 \%$ range of uncertainty of the measurement.

\subsection{Chain length}

The ozone destruction cycle as described in Reactions (R1)(R3) is a chain reaction mechanism catalyzed by $\mathrm{BrO}_{x}$. The effectiveness of a catalytic cycle can be quantified by considering the chain length, that is, the number of free radical propagation cycles per termination or per initiation. The radical chain length is a metric that refers solely to gas-phase reactions (Monks, 2005). We have not, until the OASIS 2009 campaign, had the high quality measurements available to enable a reliable estimation of the bromine radical chain length in the Arctic.

The length of the chain in a radical propagation cycle is limited by termination steps that destroy the chain carriers and result in relatively stable atmospheric species. Thus, the chain length can be defined as the rate of propagation divided by the rate of termination. Alternatively, the chain length can also be calculated using the rate of initiation. If the total bromine radical population is at steady state, the rate of initiation is equal to the rate of termination; thus, for shortlived radical species, the two methods for calculating chain length should be approximately equal.

Method 1: $\Phi=\frac{\Sigma(\text { Rates of propagation })}{\Sigma(\text { Rates of termination })}$
Method 2: $\Phi=\frac{\Sigma(\text { Rates of propagation })}{\Sigma(\text { Rates of initiation })}$

We used our model to calculate the chain length for bromine radical propagation across the 7 days of the simulated period using both Methods 1 and 2 as shown in Eqs. (5) and (6). Because bromine radicals are generated photolytically, the chain length is calculated for daytime only, defined here as approximately 07:00 to 21:00 Alaska standard time (AKST).

$$
\begin{aligned}
& \text { Method } 1: \Phi \mathrm{Br}=\left(2 k[\mathrm{BrO}]^{2}+J_{\mathrm{BrO}}[\mathrm{BrO}]+k[\mathrm{BrO}][\mathrm{ClO}]\right. \\
& \quad+k[\mathrm{BrO}][\mathrm{IO}]+k[\mathrm{BrO}]\left[\mathrm{CH}_{3} \mathrm{OO}\right] \\
& \quad+k[\mathrm{BrO}][\mathrm{OH}]+k[\mathrm{BrO}]\left[\mathrm{O}\left({ }^{3} \mathrm{P}\right)\right] \\
& \left.+k[\mathrm{BrO}]\left[\mathrm{CH}_{3} \mathrm{COOO}\right]+k[\mathrm{BrO}][\mathrm{NO}]\right) \\
& \quad+k[\mathrm{Br}]\left[\mathrm{HO}_{2}\right]+k[\mathrm{Br}]\left[\mathrm{C}_{2} \mathrm{H}_{2}\right]+k[\mathrm{Br}]\left[\mathrm{C}_{2} \mathrm{H}_{4}\right] \\
& \quad+k[\mathrm{Br}]\left[\mathrm{C}_{3} \mathrm{H}_{6}\right]+k[\mathrm{Br}][\mathrm{HCHO}]+k[\mathrm{Br}]\left[\mathrm{NO}_{2}\right] \\
& \quad+k[\mathrm{Br}]\left[\mathrm{CH}_{3} \mathrm{CHO}\right]+k[\mathrm{Br}]\left[\mathrm{C}_{3} \mathrm{H}_{6} \mathrm{O}\right]+k[\mathrm{Br}]\left[\mathrm{C}_{4} \mathrm{H}_{8} \mathrm{O}\right] \\
& \quad+k[\mathrm{Br}]\left[\mathrm{CH}_{3} \mathrm{OOH}\right]+k[\mathrm{BrO}]\left[\mathrm{HO}_{2}\right]+k[\mathrm{BrO}]\left[\mathrm{CH}_{3} \mathrm{OO}\right] \\
& \left.\quad+k[\mathrm{BrO}]\left[\mathrm{C}_{3} \mathrm{H}_{6} \mathrm{O}\right]+k[\mathrm{BrO}]\left[\mathrm{NO}_{2}\right]\right)
\end{aligned}
$$

Method $2: \Phi \mathrm{Br}=\left(2 k[\mathrm{BrO}]^{2}+J_{\mathrm{BrO}}[\mathrm{BrO}]+k[\mathrm{BrO}][\mathrm{ClO}]\right.$

$$
\begin{aligned}
& +k[\mathrm{BrO}][\mathrm{IO}]+k[\mathrm{BrO}]\left[\mathrm{CH}_{3} \mathrm{OO}\right] \\
& +k[\mathrm{BrO}][\mathrm{OH}]+k[\mathrm{BrO}]\left[\mathrm{O}\left({ }^{3} \mathrm{P}\right)\right] \\
& \left.+k[\mathrm{BrO}]\left[\mathrm{CH}_{3} \mathrm{COOO}\right]+k[\mathrm{BrO}][\mathrm{NO}]\right) \\
& \hline\left(2 J_{\mathrm{Br}_{2}}\left[\mathrm{Br}_{2}\right]+J_{\mathrm{BrCl}[\mathrm{BrCl}]+J_{\mathrm{HOBr}}[\mathrm{HOBr}]}+J_{\mathrm{BrONO}_{2}\left[\mathrm{BrONO}_{2}\right]+J_{\mathrm{IBr}}[\mathrm{Br}]+J_{\mathrm{BrNO}_{2}}\left[\mathrm{BrNO}_{2}\right]}+J_{\mathrm{CHBR}_{3}}\left[\mathrm{CHBr}{ }_{3}\right]+k[\mathrm{HBr}][\mathrm{OH}]+k\left[\mathrm{CH}_{3} \mathrm{Br}\right][\mathrm{OH}]\right. \\
& \left.+k\left[\mathrm{CHBr}_{3}\right][\mathrm{OH}]\right)
\end{aligned}
$$

Termination reactions for bromine include those reactions that are sinks for either $\mathrm{Br}$ or $\mathrm{BrO}$, since $\mathrm{Br}$ and $\mathrm{BrO}$ rapidly interconvert. Here, photolysis of $\mathrm{BrO}$ and the $\mathrm{BrO}+\mathrm{NO}$ reaction is included in the numerator because they are efficient at reforming $\mathrm{Br}$ and propagating the chain; however, these reactions do not result in a net loss of ozone. Photolysis of $\mathrm{BrO}$ produces atomic oxygen that reacts with $\mathrm{O}_{2}$ to form $\mathrm{O}_{3}$, and $\mathrm{NO}_{2}$ can photolyze to similarly reform $\mathrm{O}_{3}$. Therefore, it should be noted that if we omit these reactions and consider only those that result in a net $\mathrm{O}_{3}$ loss, it would be expected that the chain length would be shorter. Indeed, model simulations were performed without these two terms and the determined chain lengths were on average $80 \%$ lower than those presented here. $\mathrm{A} \mathrm{BrO}$ reaction with $\mathrm{CH}_{3} \mathrm{OO}$ is included in both the numerator and denominator in Eq. (5) because this reaction has two channels, one that propagates the $\mathrm{Br}$ chain and one that terminates it.

In Fig. 3, we present the hourly averaged results of these calculations for the base model, which show that the two methods for calculating bromine chain length are in reasonably good agreement, although there are small differences between the two methods throughout the time series. This agreement is a test of our basic understanding of the radical chemistry. The inset graph in Fig. 3 shows a linear regression of the two methods for the chain length calculation. The 


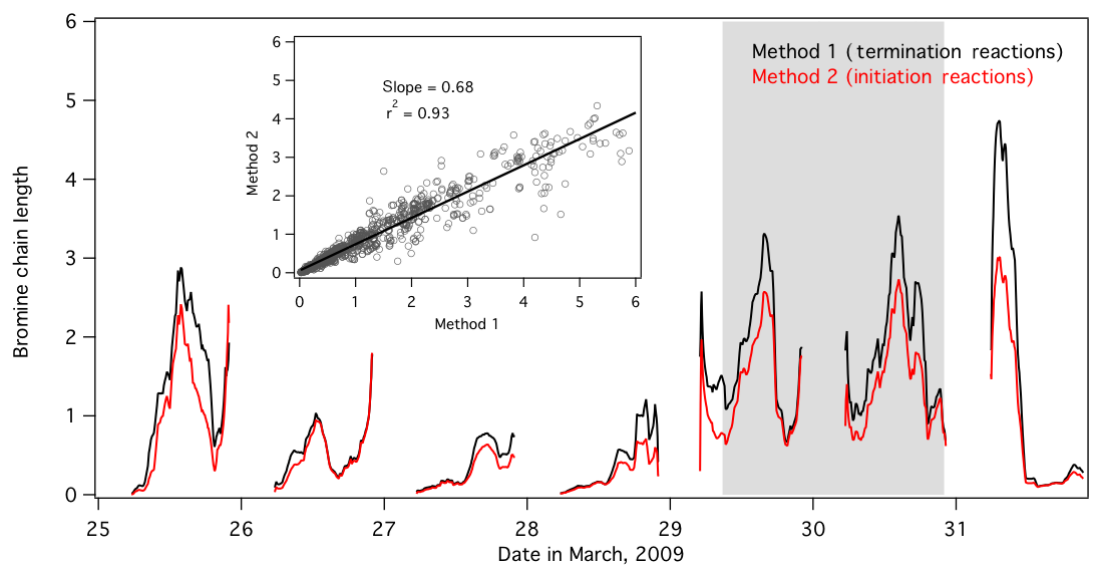

Figure 3. Time series of model-calculated bromine chain length for the daytime hours (07:00 to 21:00 AKST). Method 1 is plotted as the black trace and Method 2 is plotted as the red trace. Model output is smoothed by hourly averaging. The grey-shaded box represents a period of missing $\mathrm{Br}_{2}$ observations. The inset graph shows a linear regression of Method 1 and Method 2 calculations. Time is expressed in Alaska standard time.

coefficient of determination $\left(r^{2}\right)$ of 0.93 confirms the good temporal agreement between the two methods. However, the slope of 0.68 indicates that Method 1 is generally higher than Method 2 throughout (with some periods of exception). This offset reveals that either Method 1 is slightly overestimating the chain length or that Method 2 is underestimating it. The numerator is identical in Eqs. (5) and (6); therefore, the denominator must be driving this discrepancy, with either the denominator term in Method 1 too low or the denominator term in Method 2 too high (or some combination thereof). If it is the case that the Method 1 denominator is too low, then it must be concluded that there are important $\mathrm{BrO}_{x}$ terminations that are missing from the calculation. If, however, the denominator of Method 2 is too high, this would imply that our measurements of these $\mathrm{BrO}_{x}$ precursors are too high, which, as discussed above, is a known possibility at least for the $\mathrm{Br}_{2}$ measurements. The photolysis of $\mathrm{Br}_{2}$ is the dominant initiation pathway (see Sect. 3.3); therefore, the Method 2 chain length calculation would be the most sensitive to $\mathrm{Br}_{2}$ measurement inaccuracies.

In Eq. (6), we included photolysis of the most prevalent organobromine compound bromoform for completeness, though it has been recognized for many years that the rate of $\mathrm{Br}$ atom production from this pathway is small (e.g., $\sim 100$ molecules $\mathrm{cm}^{-3} \mathrm{~s}^{-1}$ for bromoform at midday) compared to $\mathrm{Br}$ atom production from $\mathrm{Br}_{2}$ photolysis $\left(\sim 1.3 \times 10^{7}\right.$ molecules $\mathrm{cm}^{-3} \mathrm{~s}^{-1}$ at midday assuming $5 \mathrm{pptv}$ of $\left.\mathrm{Br}_{2}\right)$. Photolysis of bromine nitrate $\left(\mathrm{BrONO}_{2}\right)$ and nitryl bromide $\left(\mathrm{BrNO}_{2}\right)$ are also included; however, the prevalence and production of these compounds in the Arctic is highly uncertain, and no observations of these species in the Arctic have been published to date with which to compare to our modeled mixing ratios. Inclusion of these terms at the modeled $\mathrm{BrONO}_{2}$ and $\mathrm{BrNO}_{2}$ mixing ratios has a small effect on the calculated chain length that cannot account for the discrepancy between the two methods.

The median bromine chain length in the base simulation, averaging the results from Method 1 and Method 2, is $\sim 1.2$ across daylight hours (07:00 to 21:00 AKST) and $\sim 2$ for afternoon hours, defined for this purpose as approximately 12:00 to 18:00 AKST, when $\left[\mathrm{O}_{3}\right] \geq 5$ ppbv. In comparison, the bromine chain length is $\sim 0.4$ when $\left[\mathrm{O}_{3}\right]<5$ ppbv (Fig. 3). In other words, the chain cannot be maintained when $\left[\mathrm{O}_{3}\right]<5$ ppbv. Under these conditions, $\mathrm{Br}$ atoms readily terminate, e.g., via reaction with $\mathrm{CH}_{3} \mathrm{CHO}$ (see below). On 29 March there is an early morning enhancement in the chain length. This morning spike appears to correlate with a similar sharp increase in ozone. $\mathrm{Br}_{2}$ accumulates during the nighttime hours, resulting in the highest $\mathrm{Br}_{2}$ concentrations in the early morning hours (Fig. 1b). When the sun rises, $\mathrm{Br}_{2}$ photolyzes rapidly, releasing a pulse of reactive bromine that converts to $\mathrm{BrO}$ in the presence of ozone. This, in concert with the coincident increase in ozone, can explain the enhanced chain length during the early morning hours.

Overall, midday bromine chain lengths remain near or below 2 during background $\mathrm{O}_{3}$ days. This implies that, for these days, ozone depletion is strongly dependent upon initiation processes, and most $\mathrm{BrO}$ radicals produced terminate the chain via Reactions (R5) and (R10) (see below) in less than two cycles. Reaction (R12) (see below) will also efficiently terminate the chain; however, the relative importance of Reactions (R10) and (R12) depend upon the relative abundances of $\mathrm{BrO}$ and $\mathrm{Br}$. For background $\mathrm{O}_{3}$ days, such as 29 and 30 March, $[\mathrm{BrO}]>[\mathrm{Br}]$; thus, Reaction $(\mathrm{R} 10)>$ Reaction (R12). The low chain lengths calculated here are surprising, given that it has been generally accepted that $\mathrm{Br}$ is recycled efficiently in the gas phase. That it appears this is not the case supports the conclusions of Michalowski et al. (2000), Piot and von Glasow (2008), and 
Toyota et al. (2014) that heterogeneous recycling through the "bromine explosion", which emits $\mathrm{Br}_{2}$ and $\mathrm{BrCl}$ from surface reactions, is of critical importance to sustain ODEs from occurring at the surface.

A question to address regarding the relatively small chain length calculated for $\mathrm{Br}$ is to what extent the chain length is dependent on $\mathrm{NO}_{2}$. As discussed in Thompson et al. (2015) and further investigated in Custard et al. (2015), $\mathrm{NO}_{2}$ at Barrow can be greater and more variable than at very remote sites due to its proximity to anthropogenic emissions sources. We find that the chain length calculation is relatively insensitive to $\mathrm{NO}_{2}$ concentrations and so it is robust for the range of conditions encountered at Barrow. This is shown in detail in Custard et al. (2015). As discussed by Custard et al. (2015), while $\mathrm{NO}_{2}$ can inhibit the bromine chain through Reactions (R10) and (R12) (i.e., decreasing the chain length), enhanced $\mathrm{NO}_{2}$ will also reduce available $\mathrm{HO}_{2}$, thereby decreasing the $\mathrm{HO}_{2}$ available to terminate the chain (i.e., increasing the chain length). While the Method 2 calculation does not contain $\mathrm{NO}_{2}$ in the denominator, the absolute $[\mathrm{BrO}]$ is $\mathrm{NO}_{x}$ dependent because of Reaction (R10) (Custard et al., 2015), and it is through this effect that high $\mathrm{NO}_{x}$ mixing ratios act to decrease the rate of $\mathrm{O}_{3}$ depletion. In the natural environment, $\mathrm{Br}_{2}$ production can potentially also be $\mathrm{NO}_{x}$ dependent, e.g., via Reaction (R11), followed by Reaction (R7). While our model does not simulate the condensed-phase processes, it is implicitly sensitive to them, since the model is constrained to the product of those processes, $\mathrm{Br}_{2}$.

$$
\begin{aligned}
& \mathrm{BrO}+\mathrm{NO}_{2} \rightarrow \mathrm{BrONO}_{2} \\
& \mathrm{BrONO}{ }_{2(\mathrm{aq})}+\mathrm{H}_{2} \mathrm{O} \rightarrow \mathrm{HOBr}+\mathrm{HNO}_{3} \\
& \mathrm{Br}+\mathrm{NO}_{2} \rightarrow \mathrm{BrNO}_{2}
\end{aligned}
$$

On the other hand, for the period of 26 through 30 March, $\mathrm{NO}_{x}$ was relatively low, and the relatively good agreement between the two calculation methods further supports our conclusion.

To investigate how chemical interactions with chlorine and iodine affect the bromine chain length, a series of simulations was performed by varying the combinations of halogens present in the model. The bromine chain length was determined for scenarios with only $\mathrm{Br}, \mathrm{Br}$ and $\mathrm{Cl}$ (base model), $\mathrm{Br}$ and iodine, and base with iodine. Simulations without chlorine were performed simply by removing $\mathrm{Cl}_{2}$, while simulations with iodine were performed by incorporating the $\mathrm{I}_{2}$ flux as described in Sect. 2.2. No other adjustments were made to the model for these sensitivity runs.

Table 2 shows the results for both chain length calculation methods (i.e., Eqs. 5 and 6) for the different halogen combinations for the 3 days when ozone was present near background values: 25, 29, and 30 March. For the base scenario ("Br and $\mathrm{Cl}$ "), the average of the median daily values for the bromine chain length is 1.43 and 1.05 for Method 1 and Method 2, respectively. In comparison with the "Br Only" run, $\mathrm{Cl}$ chemistry does not induce a net increase in the $\mathrm{Br}$ chain length, but rather causes a slight decrease. $\mathrm{Cl}$ chemistry can increase $\mathrm{Br}$ radical propagation through the addition of the $\mathrm{BrO}+\mathrm{ClO}$ cross-reaction and enhancement of the $\mathrm{BrO}+\mathrm{CH}_{3} \mathrm{OO}$ radical propagation terms. However, $\mathrm{Cl}$ chemistry can also increase the concentration of reactive bromine sinks, such as aldehydes (e.g., propanal and butanal, which were free to evolve in our model; $\mathrm{HCHO}$ and $\mathrm{CH}_{3} \mathrm{CHO}$ are fixed to observations) and $\mathrm{HO}_{2}$ (see Thompson et al., 2015). Iodine has the effect of increasing the $\mathrm{Br}$ chain length. When low levels of iodine are added to the "Bronly" simulation, the chain increases from 1.52 to 1.59 in the Method 1 calculation, primarily due to the very fast crossreaction between $\mathrm{IO}$ and $\mathrm{BrO}$. The addition of $\mathrm{Cl}$ to the " $\mathrm{Br}$ and I" simulation imparts a slight decrease to the $\mathrm{Br}$ chain length. This may be explained by the competition between $\mathrm{BrO}$ and $\mathrm{ClO}$ for reaction with $\mathrm{NO}$ and/or IO, as well as the additional $\mathrm{Br}$ sinks in the presence of $\mathrm{Cl}$ chemistry. Regardless, overall there is more $\mathrm{Br}$ available for reaction with $\mathrm{O}_{3}$ when $\mathrm{Cl}$ is present due to the interhalogen reactions, thereby increasing the rate of ozone depletion (see Thompson et al., 2015 , for further discussion on ozone depletion rates).

There are several conclusions that can be drawn from Fig. 3 and Table 2: (1) there is a distinct difference in bromine chain length between $\mathrm{O}_{3}$-depleted and non-depleted days with a significantly larger chain length when ozone is present, and (2) for all simulations, the average bromine chain is much shorter than often expected (given that gasphase recycling has, to date, been assumed to be highly efficient). The chain length is the greatest when ozone is present because many of the species that propagate the $\mathrm{Br}$ chain (e.g., $\mathrm{BrO}, \mathrm{ClO}$, IO, and to a lesser extent $\mathrm{OH}$ and $\mathrm{CH}_{3} \mathrm{OO}$ ) require $\mathrm{O}_{3}$ for production. Although the relationship between bromine chain length and $\mathrm{BrO}$ is not straightforward due to the multitude of interactions between $\mathrm{BrO}$ and other species that either propagate or terminate the chain, the chain length does exhibit a rough dependence on $[\mathrm{BrO}]$, as shown in Fig. 4, which can be loosely described with a linear fit. If it were the case that the gas-phase $\mathrm{Br}$ chain length was relatively long (such that the numerator far outweighs the denominator), and dominated by the $\mathrm{BrO}$ self-reaction, the numerator in Eqs. (5) and (6) would reduce to $2 k[\mathrm{BrO}]^{2}$, and the regression in Fig. 4 would display a quadratic fit; however, that is not observed here.

For purposes of comparison, the chain lengths for $\mathrm{Cl}$ and I were also calculated in a manner analogous to that of Eq. (5). These results are shown as hourly averages in Fig. 5 for the base with iodine scenario. It is apparent from this figure that reactive chlorine exhibits an exceptionally short chain length, whereas reactive iodine has a relatively long chain length. The average $\mathrm{Cl}$ chain length across the 3 days of background ozone $(25,29$, and 30 March) is 0.15 , or 0.23 considering only afternoon hours (12:00-18:00 AKST). This result indicates that nearly all $\mathrm{Cl}$ atoms that are produced terminate, likely through the very efficient reaction with a multitude of VOCs, as shown in Thompson et al. (2015). This behav- 
Table 2. Median afternoon bromine chain lengths for 25, 29, and 30 March 2009 (days with $\mathrm{O}_{3}$ present) determined for four different modeling scenarios with different combinations of halogens present. Method 1 refers to Eq. (3) (using terminations reactions) and Method 2 refers to Eq. (4) (using initiation reactions).

\begin{tabular}{lrr|rr|rr|rr}
\hline & \multicolumn{2}{c}{ 25 March } & \multicolumn{2}{c|}{ 29 March } & \multicolumn{2}{c}{ 30 March } & \multicolumn{2}{c}{ Average (1 $\sigma$ SD) } \\
\cline { 2 - 8 } & Method 1 & Method 2 & Method 1 & Method 2 & Method 1 & Method 2 & Method 1 & Method 2 \\
\hline Br only & 1.25 & 0.85 & 1.51 & 1.10 & 1.79 & 1.40 & $1.52( \pm 0.27)$ & $1.11( \pm 0.28)$ \\
Br and Cl (base) & 1.29 & 0.84 & 1.43 & 1.03 & 1.58 & 1.29 & $1.43( \pm 0.14)$ & $1.05( \pm 0.22)$ \\
Br and Low I & 1.37 & 0.86 & 1.60 & 1.12 & 1.82 & 1.41 & $1.59( \pm 0.22)$ & $1.13( \pm 0.28)$ \\
Br, Cl, and I & 1.37 & 0.87 & 1.51 & 1.04 & 1.65 & 1.31 & $1.51( \pm 0.14)$ & $1.07( \pm 0.23)$ \\
\hline
\end{tabular}

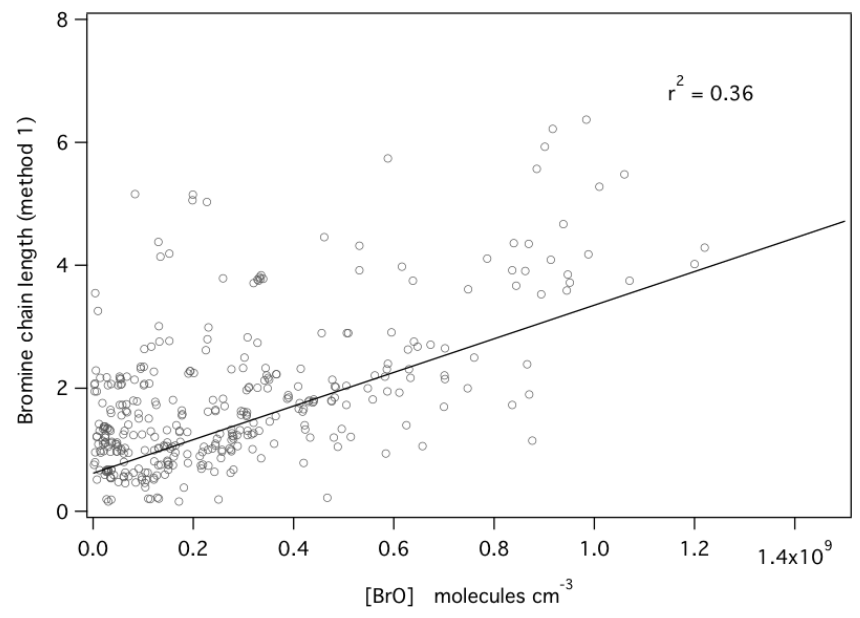

Figure 4. Regression of daytime (07:00-21:00 AKST) bromine chain length calculated by Method 1 (Eq. 5) and simulated $\mathrm{BrO}$ concentration.

ior also helps explain why $\mathrm{Cl}$ has only a small effect on the bromine chain length. In contrast, I and IO have few known sinks, which results in a reactive iodine chain length of 5.7 on average over 25, 29, and 30 March, and 7.3 over only midday hours, with maxima over 12 . The high efficiency of the gasphase regeneration of $\mathrm{I}$ in part explains why iodine is more efficient on a per atom basis at depleting ozone than either $\mathrm{Br}$ or $\mathrm{Cl}$ (Thompson et al., 2015).

\subsection{Reactive bromine initiation, propagation, and termination pathways}

The individual reactions that initiate, propagate, and terminate the reactive bromine chain were examined to determine the most important reaction pathways contributing to the chain reactions. The rates of $\mathrm{Br}$ atom production from the most important initiation pathways are shown as hourly averages in Fig. 6, with the $y$ axes expressed as the cumulative rate of reaction, including all five precursors. These are reactions that produce $\mathrm{Br}$ atoms from stable reservoir species, which is an important distinction from the propagation reactions that produce $\mathrm{Br}$ atoms through radical reactions. $\mathrm{Br}_{2}$

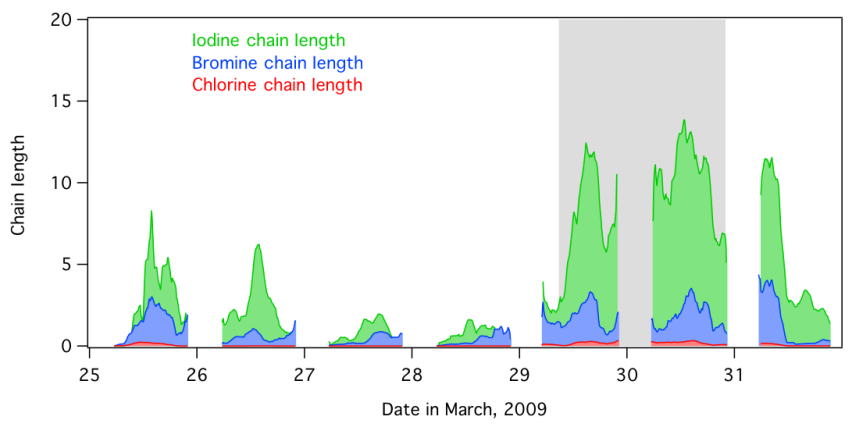

Figure 5. Calculated chain lengths for iodine (green), bromine (blue), and chlorine (red) across the 7 days of the simulated period modeled using the base + iodine scenario. Model output is smoothed by hourly averaging. The grey-shaded box represents a period of missing $\mathrm{Br}_{2}$ observations. Time is expressed in Alaska standard time.

photolysis is calculated as $2 \times \mathrm{Jr}_{2}\left[\mathrm{Br}_{2}\right]$. Here, we do not separate $\mathrm{Br}_{2}$ produced in the gas-phase versus that directly emitted from a surface (this will be discussed further in Sect. 3.5). The contribution of $\mathrm{Br}_{2}$ photolysis in producing $\mathrm{Br}$ atoms vastly dominates the cumulative production rate (Fig. 6a). Therefore, in Fig. $6 \mathrm{~b}$ we show the initiation terms without $\mathrm{Br}_{2}$ photolysis so that these other production pathways can be visualized.

Effectively, $\mathrm{Br}_{2}$ photolysis alone controls the production of bromine atoms, while combined the remaining initiation pathways add only a minor contribution. Among the minor pathways, $\mathrm{HOBr}$ photolysis is the most significant during non-ODE days, with the exception of the high $\mathrm{NO}_{x}$ period of 25 March, where $\mathrm{BrNO}_{2}$ has the largest impact. In a highly polluted environment, halogen cycling through $\mathrm{NO}_{x}$ reservoirs would become significantly more important, as has been observed with $\mathrm{ClNO}_{2}$ in mid-latitude regions (Thornton et al., 2010; Mielke et al., 2011; Young et al., 2012). The small contribution of $\mathrm{HOBr}$ photolysis to bromine atom production is an important point, because the gas-phase $\mathrm{BrO}+\mathrm{HOBr} \rightarrow \mathrm{BrO}+\mathrm{HO}_{2}$ ozone depletion cycle (that proceeds via $\mathrm{HOBr}$ photolysis rather than surface deposition) has been previously considered to be significant (see, e.g., Hausmann and Platt, 1994), though Zeng et al. (2006) noted 

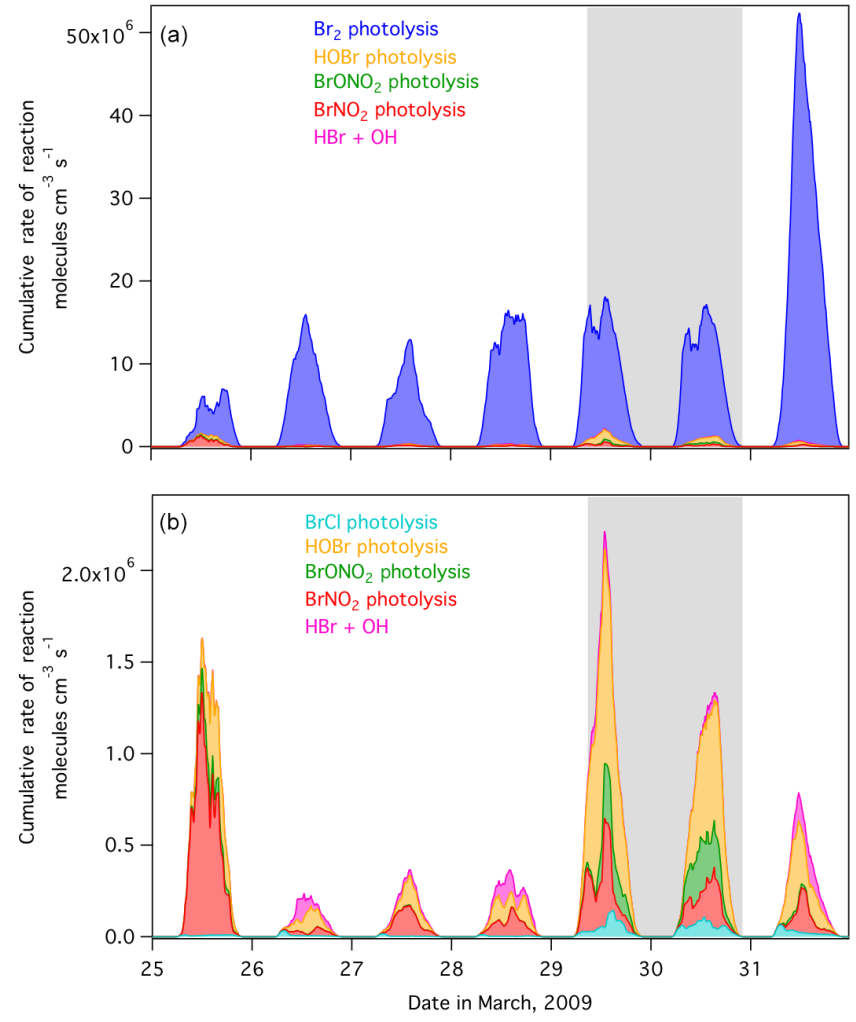

Figure 6. Time-varying rates of the most important bromine initiation reactions in the base model. Panel (a) includes photolysis of $\mathrm{Br}_{2}$, which dominates the bromine initiation. $\mathrm{Br}_{2}$ photolysis is calculated as $2 \times J_{\mathrm{Br}_{2}}\left[\mathrm{Br}_{2}\right]$. In panel (b), $\mathrm{Br}_{2}$ photolysis has been removed so that the minor terms can be visualized. Panel (b) also includes $\mathrm{BrCl}$, which contributes only a negligible amount to bromine initiation. Model output is smoothed by hourly averaging. The $y$ axis is expressed as a cumulative rate of reaction. The grey-shaded box represents a period of missing $\mathrm{Br}_{2}$ observations. Time is expressed in Alaska standard time.

that $\mathrm{HOBr}$ photolysis has only a small effect on $\mathrm{BrO}_{x}$ cycling. Using the version of our model that is unconstrained by $\mathrm{HOBr}$, but incorporates a larger surface deposition in order to reproduce observations (Fig. 2c), we were able to determine that photolysis accounts for $19 \%$ of the HOBr sink integrated over the 7-day simulation period. Surface deposition accounts for $80 \%$, and other known gas-phase reactions $(\mathrm{HOBr}+\mathrm{Br}, \mathrm{HOBr}+\mathrm{Cl}, \mathrm{HOBr}+\mathrm{OH}, \mathrm{HOBr}+\mathrm{O})$ are only minor sink terms at a combined $1 \%$.

The cumulative rates of reaction of the most important propagation pathways, with and without iodine, are shown in Fig. 7a and b. The rate of the $\mathrm{BrO}+\mathrm{BrO}$ reaction is calculated as $2 k[\mathrm{BrO}]^{2}$, since this reaction results in the production of two $\mathrm{Br}$ atoms. The reaction pathways that dominate the bromine propagation, i.e., $\mathrm{BrO}$ photolysis and reaction with NO, are those that do not result in a net ozone loss. This has been previously recognized and applied to $\mathrm{Br}$ steadystate calculations in several works (e.g., Platt and Janssen,
1995; Zeng et al., 2006; Holmes et al., 2010), and demonstrates that much of the time $\mathrm{BrO}$ regenerates $\mathrm{Br}$ without a net loss of ozone for the simulated conditions in Barrow. Indeed, in our previous paper, we calculated that $\sim 70 \%$ of gasphase $\mathrm{BrO}$ reforms ozone via photolysis or reaction with $\mathrm{NO}$ over this period (Thompson et al., 2015). The inset pie charts, which show the average fractional importance of the various propagation reactions for 29 and 30 March, reveal that these two pathways account for 88-91\% of the total. Interestingly, the $\mathrm{BrO}$ self-reaction is small in comparison, with an average contribution of 5-6\%, and a maximum of $46 \%$. However, if we consider only those reactions that $d o$ lead to a net ozone loss, then the $\mathrm{BrO}$ self-reaction accounts for an average of $71 \%$ and a maximum of $98 \%$ of the propagation. The rate of the $\mathrm{BrO}+\mathrm{ClO}$ reaction rate is much smaller than that for $\mathrm{BrO}+\mathrm{BrO}$, though not insignificant. While on average this reaction pathway accounts for only $2 \%$, it does reach $16 \%$ when $\mathrm{Cl}_{2}$ is high on 29 March. In considering only those reactions that result in a net ozone loss, the $\mathrm{BrO}+\mathrm{ClO}$ pathway accounts for $21 \%$ on average, and up to a maximum of $57 \%$. In panel $\mathrm{b}$, the base with iodine scenario is shown. At these levels, the $\mathrm{BrO}+\mathrm{IO}$ reaction accounts for $4 \%$ of the propagation, which is at times comparable to $\mathrm{BrO}+\mathrm{BrO}$ and greater than $\mathrm{BrO}+\mathrm{ClO}$, even at the low $\mathrm{IO}$ mixing ratios in this simulation $(\sim 1 \mathrm{pptv})$.

The short gas-phase chain length calculated for bromine propagation indicates that there are large reactive bromine $\left(\mathrm{BrO}_{x}\right)$ sinks terminating the chain reaction. Figure 8 presents the rates of the most important $\mathrm{BrO}_{x}$ termination reactions, with the $y$ axis expressed as the cumulative rate of reaction. Here it can be seen that reaction of $\mathrm{BrO}$ with $\mathrm{NO}_{2}$ is the dominant sink for $\mathrm{BrO}_{x}$ on non-ODE days for the conditions encountered at Barrow, while $\mathrm{Br}$ reaction with $\mathrm{CH}_{3} \mathrm{CHO}$ is most important when $\mathrm{O}_{3}$ is depleted. That $\mathrm{HO}_{2}$ is a significant sink, and would be more so in less anthropogenically impacted polar regions, points toward the importance of heterogeneous recycling through the bromine explosion mechanism. During ozone depletion, such as the major event from the days 26 to -28 March $\left(\left[\mathrm{O}_{3}\right]<5 \mathrm{ppbv}\right)$ when $\mathrm{BrO}$ is mostly absent, $\mathrm{CH}_{3} \mathrm{CHO}$ becomes the primary sink term for $\mathrm{Br}$, and $\mathrm{HCHO}$ is relatively more important. The strength of the $\mathrm{CH}_{3} \mathrm{CHO}$ sink is much greater than is $\mathrm{HCHO}$, as noted previously by Shepson et al. (1996) and Bottenheim et al. (1990). Of note are the relatively similar magnitudes for the total rate of reaction of the initiation, propagation, and termination reactions shown in Figs. 6, 7, and 8, respectively, which of course must be the case for a chain length near 1 . This accounts for the short bromine chain length determined here and also indicates that to sustain elevated bromine radical concentrations necessary to deplete $\mathrm{O}_{3}$ requires a relatively large $\mathrm{Br}_{2}$ source, likely in the form of a significant flux of $\mathrm{Br}_{2}$ from the snow surface, or from in situ production from aerosols. 

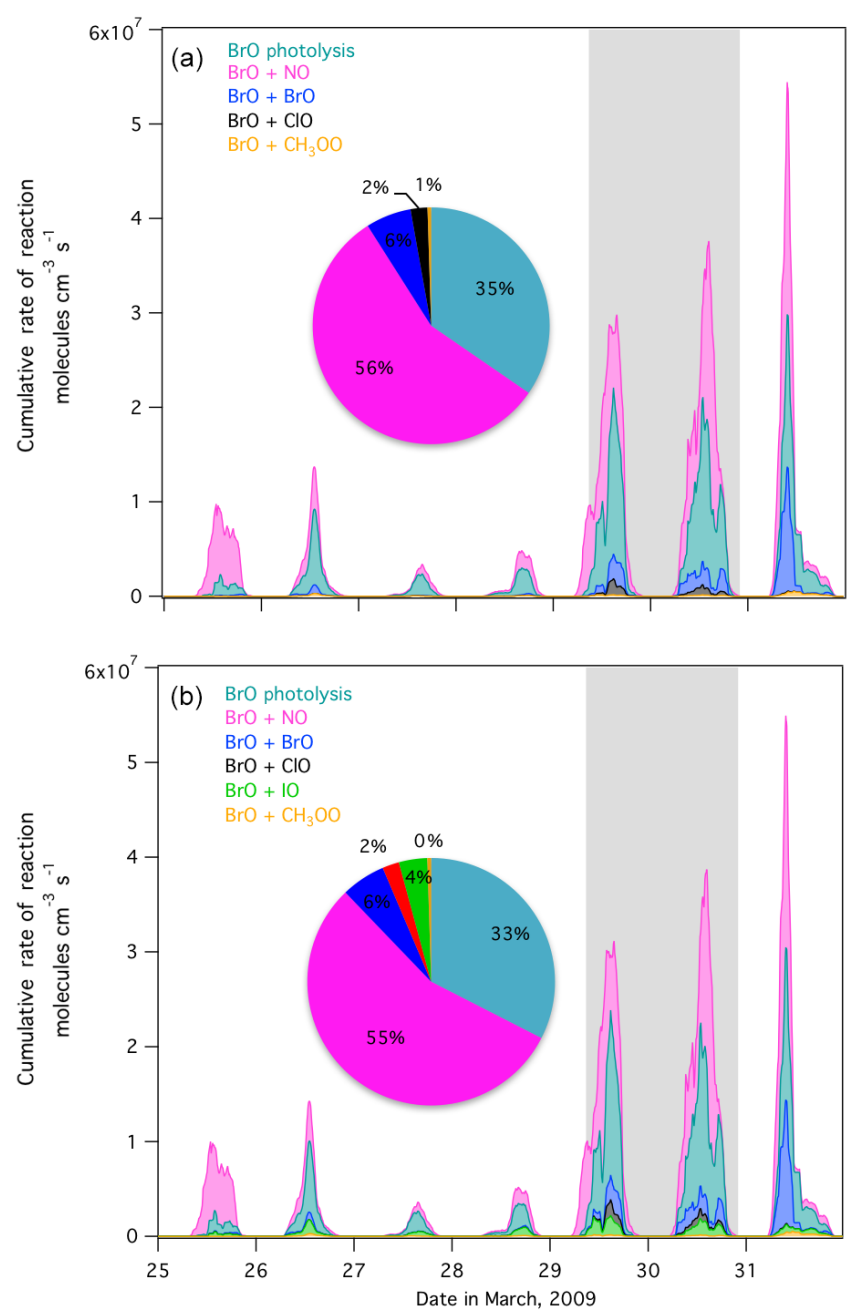

Figure 7. Time-varying rates of the most important bromine propagation reactions in the base model with $\mathrm{Br}$ and $\mathrm{Cl}$ present (a) and with iodine included (b). The $\mathrm{BrO}+\mathrm{BrO}$ reaction is calculated as $2 k[\mathrm{BrO}]^{2}$ as this reaction regenerates two $\mathrm{Br}$ atoms. Model output is smoothed by hourly averaging. The $y$ axis is expressed as a cumulative rate of reaction. The grey-shaded box represents a period of missing $\mathrm{Br}_{2}$ observations. Time is expressed in Alaska standard time. The inset pie charts show the average fractional importance of each reaction pathway for only the days of 29 and 30 March (i.e., background $\mathrm{O}_{3}$ days).

\subsection{Ozone loss rate}

Since the chain length calculations suggest a larger than expected contribution of heterogeneous bromine recycling to $\mathrm{Br}$ atom production, to examine this further, we calculated the rate of net ozone loss by $\mathrm{Br}$ and $\mathrm{Cl}$ in the base model using Eq. (7) and compared this rate to that using the estimation method presented in previous works as shown in Eq. (2) (Platt and Janssen, 1995; Le Bras and Platt, 1995). Additionally, the total simulated chemical ozone loss in the base model was calculated from Eq. (8), which includes $\mathrm{O}_{3}$

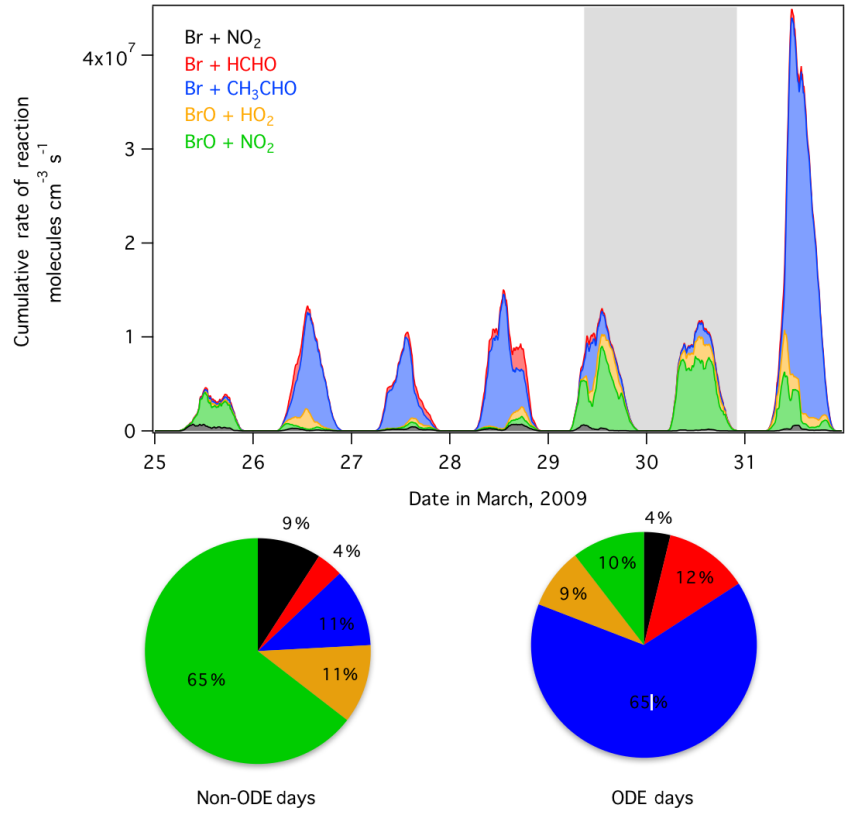

Figure 8. Time-varying rates of the most important reactive bromine $\left(\mathrm{BrO}_{x}\right)$ termination reactions in the base model. Model output is smoothed by hourly averaging. The $y$ axis is expressed as a cumulative rate of reaction. The grey-shaded box represents a period of missing $\mathrm{Br}_{2}$ observations. Time is expressed in Alaska standard time. The pie charts show the average fractional importance of each reactive bromine sink for non-ODE (background $\mathrm{O}_{3}$ ) days and ODE days.

destruction by $\mathrm{OH}, \mathrm{HO}_{2}$, and photolysis (determined here as $\left.k\left[\mathrm{O}\left({ }^{1} \mathrm{D}\right)\right]\left[\mathrm{H}_{2} \mathrm{O}\right]\right)$.

$\mathrm{O}_{3}$ Loss by $\mathrm{Br}$ and $\mathrm{Cl}=\left(k[\mathrm{Br}]\left[\mathrm{O}_{3}\right]-J[\mathrm{BrO}]-k[\mathrm{BrO}][\mathrm{NO}]\right)$

$$
+\left(k[\mathrm{Cl}]\left[\mathrm{O}_{3}\right]-J[\mathrm{ClO}]-k[\mathrm{ClO}][\mathrm{NO}]\right)
$$

Total Chemical $\mathrm{O}_{3}$ loss Rate $=k[\mathrm{Br}]\left[\mathrm{O}_{3}\right]+k[\mathrm{Cl}]\left[\mathrm{O}_{3}\right]$

$$
\begin{aligned}
& +k\left[\mathrm{O}\left({ }^{1} \mathrm{D}\right)\right]\left[\mathrm{H}_{2} \mathrm{O}\right]+k[\mathrm{OH}]\left[\mathrm{O}_{3}\right]+k\left[\mathrm{HO}_{2}\right]\left[\mathrm{O}_{3}\right] \\
& -k[\mathrm{BrO}][\mathrm{NO}]-J[\mathrm{BrO}]-k[\mathrm{ClO}][\mathrm{NO}]-J[\mathrm{ClO}]
\end{aligned}
$$

The method in Eq. (2) assumes that the rate of ozone loss is equivalent to the rate at which $\mathrm{Br}$ is regenerated through $\mathrm{BrO}$ reaction with itself and $\mathrm{ClO}$ (thus assuming efficient gasphase propagation and a long chain length), whereas Eq. (7) accounts for all net ozone destruction by $\mathrm{Br}$ and $\mathrm{Cl}$, by correcting for those reactions that release a triplet oxygen atom and reform $\mathrm{O}_{3}$. In other words, this method accounts for the fact that some $\mathrm{BrO}$ radicals react to terminate the chain (and at steady state, an equivalent $\mathrm{BrO}_{x}$ production rate is necessary). Figure 9a compares these two estimations for $\mathrm{O}_{3}$ loss rate in green (Eq. 2) and pink (Eq. 7). This comparison clearly shows that there is a large difference between the methods, with the estimation from Eq. (2) significantly smaller overall. Additionally, the total chemical $\mathrm{O}_{3}$ loss (calculated by Eq. 8) is shown in the dashed black trace. The $\mathrm{O}_{3}$ 

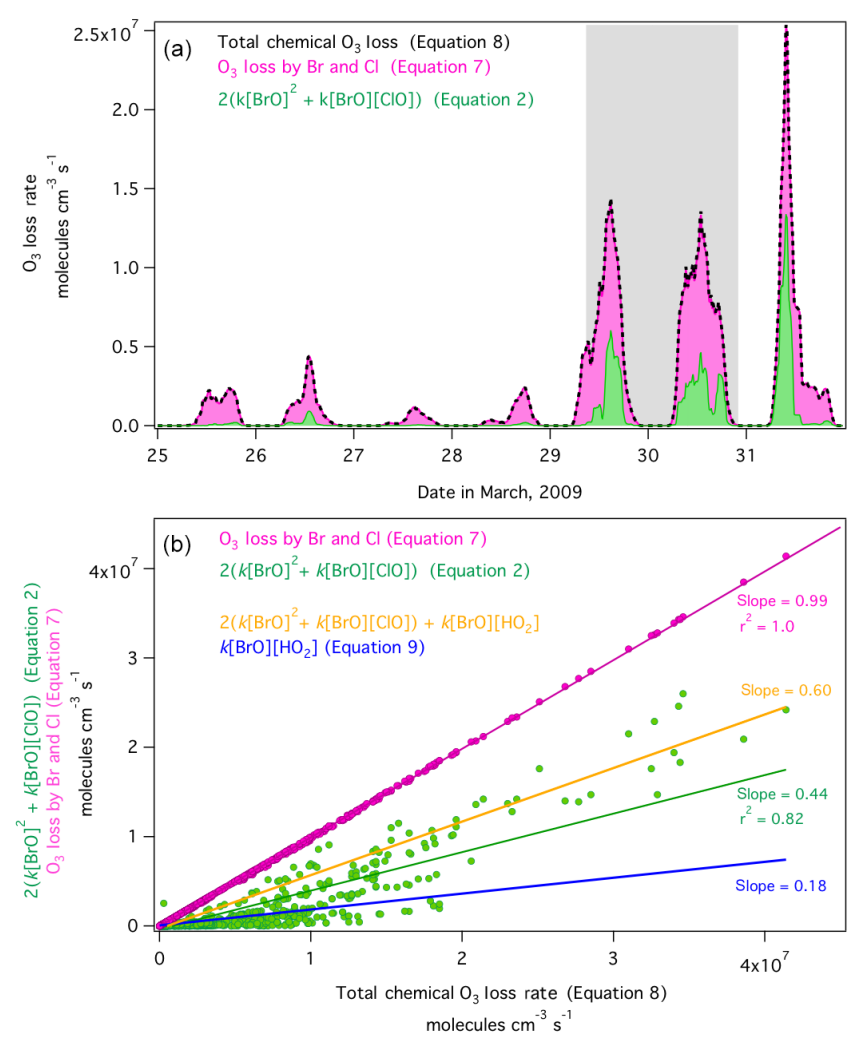

Figure 9. (a) Comparison of the time-varying $\mathrm{O}_{3}$ loss rate calculated using the estimation of $2\left(k[\mathrm{BrO}]^{2}+k[\mathrm{BrO}][\mathrm{ClO}]\right)$ (Eq. 2, green), the simulated $\mathrm{O}_{3}$ loss rate by $\mathrm{Br}$ and $\mathrm{Cl}$ (Eq. 7, pink), and the total simulated chemical $\mathrm{O}_{3}$ loss rate (Eq. 8, dashed black trace). Model output is smoothed by hourly averaging. The grey-shaded box represents a period of missing $\mathrm{Br}_{2}$ observations. Time is expressed in Alaska standard time. (b) Shown is a regression of the $2\left(k[\mathrm{BrO}]^{2}+[\mathrm{BrO}][\mathrm{ClO}]\right)$ estimation method (Eq. 2$)$ versus the total simulated chemical $\mathrm{O}_{3}$ loss rate in the base model (Eq. 8) in the green data, and a regression of $\mathrm{O}_{3}$ loss rate by $\mathrm{Br}$ and $\mathrm{Cl}$ only (Eq. 7) versus the total simulated chemical $\mathrm{O}_{3}$ loss rate in the pink data. The blue trace represents the $\mathrm{O}_{3}$ loss rate estimated by only considering $k[\mathrm{BrO}]\left[\mathrm{HO}_{2}\right]$ (Eq. 9). The orange trace estimates $\mathrm{O}_{3}$ loss rate combining the three major gas-phase ozone depletion cycles. The slopes represent the fraction of the chemical $\mathrm{O}_{3}$ loss rate that can be accounted for by each method. For the conditions simulated, the commonly used estimation method of $2\left(k[\mathrm{BrO}]^{2}+[\mathrm{BrO}][\mathrm{ClO}]\right)$ only accounts for $44 \%$ of the chemical $\mathrm{O}_{3}$ loss rate.

loss rate estimation presented in Eq. (7) accounts for nearly all of the chemical $\mathrm{O}_{3}$ loss (i.e., most chemical $\mathrm{O}_{3}$ loss is a result of halogen chemistry), such that the dashed black line lies nearly perfectly on top of the pink-shaded regions.

In Fig. 9b, we show a regression of the two estimation methods (Eq. 2 in green and Eq. 7 in pink) versus the total chemical $\mathrm{O}_{3}$ loss rate (Eq. 8). Here it can be seen from the pink data that halogen chemistry accounts for $99 \%$ of the total chemical $\mathrm{O}_{3}$ loss under the conditions simulated here. Importantly, the $\mathrm{O}_{3}$ loss rate estimation presented in Eq. (2) accounts for only $44 \%$ of the total chemical $\mathrm{O}_{3}$ loss rate.
In the work by Hausmann and Platt (1994), the authors also considered the $\mathrm{BrO}+\mathrm{HO} \rightarrow \mathrm{Br}+\mathrm{HO}_{2}$ gas-phase ozone depletion cycle as a proxy for estimating the $\mathrm{O}_{3}$ loss rate, using the equation shown below (Eq. 17 of Hausmann and Platt, 1994).

$\frac{\mathrm{d}\left[\mathrm{O}_{3}\right]}{\mathrm{d} t}=\left(k 5 \cdot[\mathrm{BrO}] \cdot\left[\mathrm{HO}_{2}\right]\right)$

The authors only considered the gas-phase cycle of $\mathrm{HOBr}$ here with the photolysis of $\mathrm{HOBr}$ regenerating $\mathrm{Br}$. At the time of this publication, the heterogeneous cycling of $\mathrm{HOBr}$ had only recently been proposed and had not been fully validated. Hausmann and Platt (1994) showed that Eq. (9) resulted in a significantly lower estimation for $\mathrm{O}_{3}$ depletion than did Eq. (1), which considered only the $\mathrm{BrO}-\mathrm{BrO}$ cycle. In Fig. 9b, we show also the $\mathrm{O}_{3}$ loss rate estimated using Eq. (9) in blue. Our results corroborate that of Hausmann and Platt (1994), and demonstrate that Eq. (9) can account for only $18 \%$ of the $\mathrm{O}_{3}$ loss. To examine this one step further, we present an additional regression in Fig. 8b (orange trace) that combines Eqs. (2) and (9), thereby considering the three predominant gas-phase $\mathrm{O}_{3}$ depletion cycles of $\mathrm{BrO}-$ $\mathrm{BrO}, \mathrm{BrO}-\mathrm{ClO}$, and $\mathrm{BrO}-\mathrm{HO}_{2}$. This still can only account for $60 \%$ of the $\mathrm{O}_{3}$ loss.

Our analysis quantitatively expresses the conclusion that the gas-phase recycling of bromine is not as efficient as previously considered and that it is often the case, for Barrow, that $\mathrm{BrO}_{x}$ terminations must often, through Reactions (R5) or (R10), be followed by heterogeneous production of $\mathrm{Br}_{2}$ through condensed-phase reactions of $\mathrm{HOBr}$ and/or $\mathrm{BrONO}_{2}$. In other words, the reproduction of $\mathrm{Br}_{2}$ via reactive deposition/uptake of $\mathrm{HOBr}$ and/or $\mathrm{BrONO}_{2}$ onto surfaces, followed by their gas-phase production via $\mathrm{BrO}+\mathrm{HO}_{2}$ and $\mathrm{BrO}+\mathrm{NO}_{2}$, respectively, plays a significant role in the catalytic ozone loss involving $\mathrm{Br}$ atoms in the Arctic boundary layer. An important conclusion from this analysis is that the chemical $\mathrm{O}_{3}$ loss rate is largely underestimated when calculated from only $\mathrm{BrO}$ observations using the previously accepted $2\left(k[\mathrm{BrO}]^{2}+[\mathrm{BrO}][\mathrm{ClO}]\right)$ method, and one should be cautious about drawing conclusions about $\mathrm{O}_{3}$ depletion rates and timescales based solely on $\mathrm{BrO}$ observations. This may have significant impacts on the process of examining ODEs and addressing the extent to which they represent local scale chemistry versus transport effects. While this situation is significantly impacted by local $\mathrm{NO}_{x}$ sources at Barrow, $\mathrm{NO}_{x}$ is expected to increase with development around the Arctic.

\subsection{Bromine atom production}

If it is the case that heterogeneous recycling is of such importance, it may be that Reaction (R5) $\left(\mathrm{BrO}+\mathrm{HO}_{2}\right)$ competes favorably with Reaction (R3) $(\mathrm{BrO}+\mathrm{BrO})$. Panel A of Fig. 10 shows the rates of Reactions (R5) and (R3). This plot demonstrates that for our modeling results, the rate of reac- 

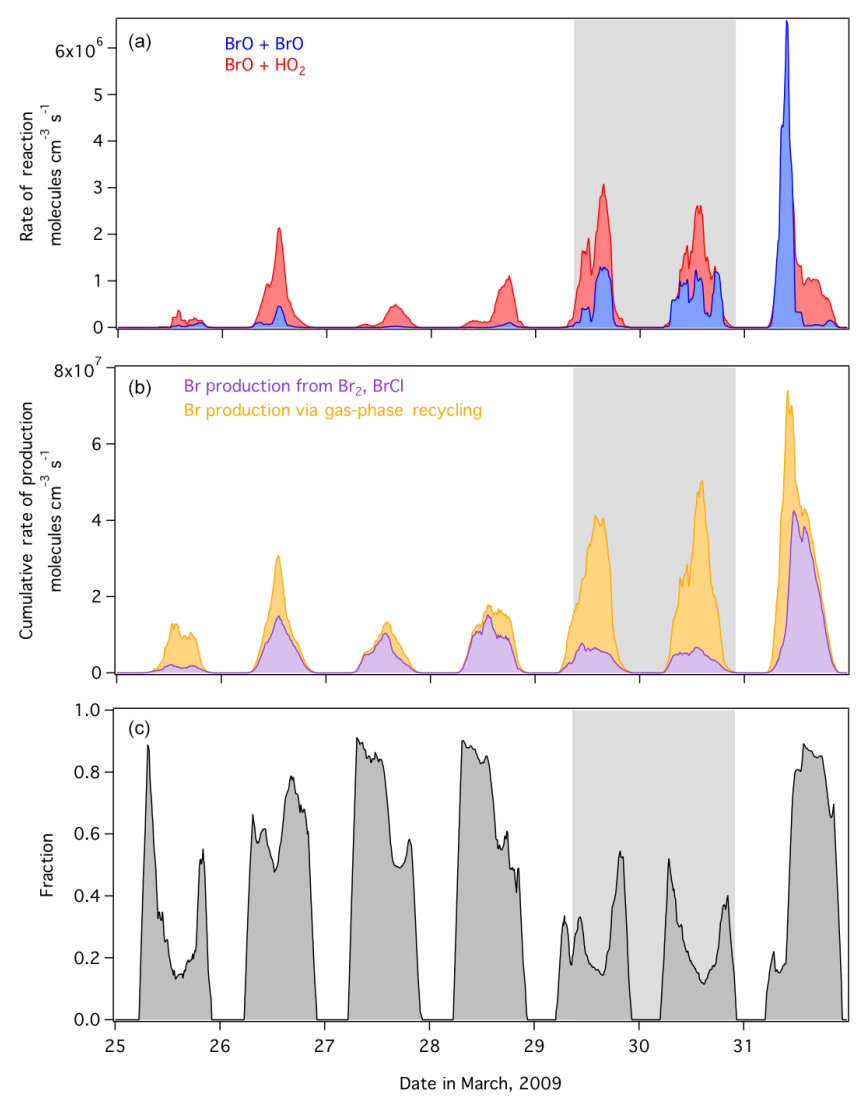

Figure 10. (a) Comparison of the rate of reaction of $\mathrm{BrO}+\mathrm{BrO}$ (blue) and $\mathrm{BrO}+\mathrm{HO}_{2}$ (red). (b) The cumulative rate of $\mathrm{Br}$ atom production separated into the $\mathrm{Br}$ production rate from the photolysis of $\mathrm{Br}_{2}$ and $\mathrm{BrCl}$ surface emissions calculated from Eq. (10) (purple) and the $\mathrm{Br}$ atom production rate due to gas-phase radical recycling calculated from Eq. (11) (orange). (c) The fraction of total $\mathrm{Br}$ atom production due to production from $\mathrm{Br}_{2}$ and $\mathrm{BrCl}$ surface emissions. In all panels, model output is smoothed by hourly averaging. The grey-shaded box represents a period of missing $\mathrm{Br}_{2}$ observations. Time is expressed in Alaska standard time.

tion of $\mathrm{BrO}$ with $\mathrm{HO}_{2}$ is often of a comparable or greater magnitude than the $\mathrm{BrO}$ self-reaction, and remains significant throughout the simulated period. Previous modeling work by Sander et al. (1997) also compared the rates of these two critical reactions (Fig. 2 of that work). In contrast to our results, their model predicted that the rate of the $\mathrm{BrO}+\mathrm{BrO}$ reaction was up to a factor of 8 greater than that of $\mathrm{BrO}+\mathrm{HO}_{2}$. The reason for this difference may perhaps be the much lower mixing ratios of $\mathrm{HO}_{2}$ in the model by Sander et al. (1997). Their model predicted $\mathrm{HO}_{2}$ daily maxima of 0.2 to $0.6 \mathrm{pptv}$ for most days, increasing to $1.8 \mathrm{pptv}$ on the final 3 days of their simulation. In contrast, $\mathrm{HO}_{2} \mathrm{ob}-$ servations at Barrow were frequently greater than 5 and up to 10 pptv. As demonstrated in Thompson et al. (2015), HCHO was a dominant factor in controlling the $\mathrm{HO}_{2}$ mixing ratios in Barrow. The low levels of $\mathrm{HO}_{2}$ in Sander et al. (1997) likely also contribute to their low predicted $\mathrm{HOBr}$ mixing ra- tios, which do not exceed $1 \mathrm{pptv}$ in their model. This also is much lower than observations at Barrow, where $\mathrm{HOBr}$ reaching 10 to 20 pptv was measured during our simulated period. Because the $\mathrm{BrO}+\mathrm{HO}_{2}$ reaction is of primary importance for the bromine explosion mechanism, our result supports the hypothesis that heterogeneous recycling may be equally, or even more, important than gas-phase recycling of reactive bromine.

Given that the chain length is small, it must be that initiation is an important source of $\mathrm{Br}$ atoms in order to sustain $\mathrm{BrO}$ and lead to $\mathrm{O}_{3}$ depletion. To further examine the question of surface emissions/release versus gas-phase recycling, we determined the rate of production of $\mathrm{Br}$ atoms via photolysis of $\mathrm{Br}_{2}$ and $\mathrm{BrCl}$ (Eq. 10) compared to the rate of production of $\mathrm{Br}$ atoms through gas-phase recycling calculated by Eq. (11). Because our model is constrained by $\mathrm{Br}_{2}$ observations and we do not produce $\mathrm{Br}_{2}$ from surfaces via heterogeneous reactions, the photolysis of $\mathrm{Br}_{2}$ includes $\mathrm{Br}_{2}$ that is both emitted from surfaces and that is formed via gasphase reactions. To correct for the $\mathrm{Br}_{2}$ that is formed in the gas-phase reactions so that Eq. (10) represents our best approximation for surface-emitted $\mathrm{Br}_{2}$, we created a proxy in the model, $\mathrm{Br}_{2}{ }^{*}$, which represents the $\mathrm{Br}_{2}$ produced from gas-phase reactions. These reactions include $\mathrm{Br}+\mathrm{BrNO}_{2}$, $\mathrm{Br}+\mathrm{BrONO}_{2}$, and the $\mathrm{BrO}+\mathrm{BrO}$ branch that produces $\mathrm{Br}_{2}$. Equation (10) is thus corrected for the gas-phase generated $\mathrm{Br}_{2}$ by subtracting the photolysis of $\mathrm{Br}_{2}{ }^{*}$. A comparison of $\mathrm{Br}_{2}$ and $\mathrm{Br}_{2}{ }^{*}$ reveals that these three gas-phase production pathways account for an average of $35 \%$ of observed $\mathrm{Br}_{2}$, suggesting that the snowpack and/or aerosols emit the remaining $65 \%$. Again, we cannot distinguish between snow or aerosol production using this method.

$\mathrm{Br}$ Production from Surface-derived $\mathrm{Br}_{2}, \mathrm{BrCl}$

$$
=2 \times J_{\mathrm{Br}_{2}}\left[\mathrm{Br}_{2}\right]+J_{\mathrm{BrCl}}[\mathrm{BrCl}]-2 \times J_{\mathrm{Br}_{2}}\left[\mathrm{Br}_{2}{ }^{*}\right]
$$

$\mathrm{Br}$ Production via Gas-phase Recycling

$$
\begin{aligned}
& =2 k[\mathrm{BrO}][\mathrm{BrO}]+k[\mathrm{BrO}][\mathrm{ClO}] \\
& +k[\mathrm{BrO}][\mathrm{NO}]+k[\mathrm{BrO}][\mathrm{OH}]+k[\mathrm{BrO}]\left[\mathrm{O}\left({ }^{3} \mathrm{P}\right)\right] \\
& +k[\mathrm{BrO}]\left[\mathrm{CH}_{3} \mathrm{OO}\right]+k[\mathrm{BrO}]\left[\mathrm{CH}_{3} \mathrm{COOO}\right] \\
& +J_{\mathrm{HOBr}}[\mathrm{HOBr}]+J_{\mathrm{BrO}}[\mathrm{BrO}]+J_{\mathrm{BrONO}_{2}}\left[\mathrm{BrONO}_{2}\right] \\
& +J_{\mathrm{BrNO}_{2}}\left[\mathrm{BrNO}_{2}\right]
\end{aligned}
$$

Figure 10b compares the results of Eqs. (10) and (11), showing the total rate of $\mathrm{Br}$ atom production separated into $\mathrm{Br}$ production from the derived "surface-emitted" $\mathrm{Br}_{2}$ and $\mathrm{BrCl}$ (purple) and from gas-phase $\mathrm{Br}$ recycling (orange); panel $\mathrm{c}$ plots the fraction of total $\mathrm{Br}$ atom production that is due to production from $\mathrm{Br}_{2}$ and $\mathrm{BrCl}$ surface emissions/release. The majority of the time during this 7-day period $\mathrm{Br}$ atom production from $\mathrm{Br}_{2}$ and $\mathrm{BrCl}$ emissions/release (Eq. 10) accounts for $30 \%$ or greater of the total, and at times reaches up to $90 \%$. This explains both how ozone depletion can be rapid despite the short calculated bromine radical chain length, as well as the difference found between the two methods of esti- 
mating $\mathrm{O}_{3}$ loss rate in Fig. 9. Therefore, it is concluded from this analysis that the condensed-phase recycling of bromine can be of equal or greater importance to the evolution of ODEs than gas-phase $\mathrm{Br}$ regeneration through radical recycling reactions.

\section{Conclusions}

The analysis presented here suggests that the gas-phase recycling of bromine species may be less important than commonly believed, and we conclude that heterogeneous recycling is critical for the evolution of ODEs/AMDEs, consistent with results by Michalowski et al. (2000), Piot and von Glasow (2008), and Toyota et al. (2011, 2014). Expressed in another way, the reproduction of $\mathrm{Br}_{2}$ via reactive deposition/uptake of $\mathrm{HOBr}$ and/or $\mathrm{BrONO}_{2}$ onto surfaces, followed by their gas-phase production via $\mathrm{BrO}+\mathrm{HO}_{2}$ and $\mathrm{BrO}+\mathrm{NO}_{2}$, respectively, is critical for sustaining the $\mathrm{Br}$ atom chemistry leading to $\mathrm{O}_{3}$ depletion in the Arctic boundary layer.

To support this conclusion, we have used the gas-phase bromine chain length, which had not previously been applied to Arctic halogen chemistry, as an objective metric. The gas-phase bromine chain length is much shorter than expected, suggesting that much of the $\mathrm{Br}$ present in the gasphase is $\mathrm{Br}$ from surface emissions/release. Again note that our calculation of chain length includes photolysis of $\mathrm{BrO}$ and $\mathrm{BrO}+\mathrm{NO}$, which do not result in net $\mathrm{O}_{3}$ loss. Had we omitted these two reactions, which we have found are in fact dominating the radical propagation, the chain length would be, on average, $80 \%$ shorter. Because of the small chain length calculated for $\mathrm{Br}$, one must be cautious about drawing conclusions about $\mathrm{O}_{3}$ depletion from $\mathrm{BrO}$ measurements alone. We recommend concurrent measurements of a broad suite of inorganic bromine species for accurate study of these ozone depletion events. The very low mixing ratios of $\mathrm{HOBr}$ predicted by Sander et al. (1997) and the high mixing ratios originally predicted by our model point to the need for measurements of these species to validate the accuracy of Arctic models.

We find that between 30 and $90 \%$ of $\mathrm{Br}$ atoms are produced from surface emissions/release of $\mathrm{Br}_{2}$ and $\mathrm{BrCl}$, though we cannot distinguish snow sources from aerosol sources using our model. However, it is important to note that we do not know how much of the condensed-phase $\mathrm{Br}_{2}$ production derives from Reaction (R7), or from some other condensed-phase process, e.g., oxidation of $\mathrm{Br}^{-}$by $\mathrm{OH}$ radicals (Abbatt et al., 2010). The in situ snow chamber experiments by Pratt et al. (2013) demonstrated a strong $\mathrm{Br}_{2}$ source from the snowpack; similar field observations proving significant $\mathrm{Br}_{2}$ release from Arctic aerosol are currently lacking. If the snow surface is the primary source of these emissions, then a strong vertical gradient would be expected in the near-surface boundary layer, and our estimations for the $\mathrm{Br}$ chain length would be only valid for the height of our measurements ( $\sim 1 \mathrm{~m}$ above the snow). Strong deposition to the snow would also induce a vertical gradient in these species. If, however, aerosols are an important source of $\mathrm{Br}_{2}$ (or other halogen precursors), then $\mathrm{Br}_{2}$ production should occur throughout the entire height of the boundary with no significant vertical gradient, in a similar fashion as has been observed for $\mathrm{ClNO}_{2}$, which is a known product of aerosol chemistry (Young et al., 2012). It is clear that vertically resolved measurements of these halogen precursors are imperative for our understanding of halogen production in the Arctic.

The production of $\mathrm{Br}_{2}$ is quite complex and is dependent on many factors, including the relative concentrations of bromide and chloride (among others), the availability of atmospheric oxidants, such as ozone (e.g., Oum et al., 1998; Pratt et al., 2013), the $\mathrm{pH}$ of the snow surfaces or aerosol (Toyota et al., 2011, 2014), the presence of snow-phase oxidants such as $\mathrm{H}_{2} \mathrm{O}_{2}$ (Pratt et al., 2013), and the replenishment of the snowpack halides from deposited sea salts. The last of these is governed by meteorology, the proximity of open water or saline sea ice surfaces, and wind/storm events, making the accurate modeling of these processes very complex (Domine et al., 2013). Likewise, to date, it has not been possible to determine the halide concentrations or $\mathrm{pH}$ of the snow grain surfaces, and these values are likely highly variable and dependent on snow and aerosol aging and deposition of atmospheric constituents. Due to the apparent importance of surface chemistry for both the initiation and evolution of Arctic ozone depletion events, it is clear that more laboratory and field studies are required to decipher these complex chemical and physical processes. In particular, we strongly recommend studies relating to direct measurements of surface fluxes of molecular halogens, as a function of conditions of temperature, snowpack composition, and $\mathrm{pH}$, as well as deposition velocities for the hypohalous acids $(\mathrm{HOBr}, \mathrm{HOCl})$ to the snow. Our model overestimation of $\mathrm{HOBr}$, which necessitated constraint to observations, suggests a sometimes much stronger, but also variable, deposition of $\mathrm{HOBr}$ that is currently unknown. Further, there is currently little understanding of the mechanism for $\mathrm{Cl}_{2}$ production in the Arctic, and no successful measurements of IO in the High Arctic. Recent observations of $\mathrm{I}_{2}$ within the Barrow snowpack (Raso et al., 2017) suggest reactive iodine chemistry is present in this region, and this would have an impact on $\mathrm{Br}$ recycling and ozone depletion rate. Investigations into these areas would greatly increase our understanding of halogen chemistry and ozone depletion in the Arctic.

Data availability. Data sets from the OASIS 2009 campaign are archived individually on the NSF Arctic Data Center site (https:// arcticdata.io) under multiple digital object identifiers all searchable using the search term "OASIS". Data sets are additionally archived on the NCAR EOL website (https://doi.org/10.5065/D6CJ8BM3). 
Competing interests. The authors declare that they have no conflict of interest.

Acknowledgements. This work was funded by the National Science Foundation grant ARC-0732556. Partial support for CT during preparation of this manuscript was provided by the NSF Atmospheric and Geospace Sciences Postdoctoral Research Fellowship program. The authors wish to thank the organizers of the OASIS 2009 field campaign, the Barrow Arctic Science Consortium for logistics support, and all of the researchers, who contributed to the campaign. This paper is submitted in memory of our colleague and friend, Roland von Glasow.

Edited by: P. Monks

Reviewed by: two anonymous referees

\section{References}

Abbatt, J., Oldridge, N., Symington, A., Chukalovskiy, V., McWhinney, R. D., Sjostedt, S., and Cox, R. A.: Release of Gas-Phase Halogens by Photolytic Generation of $\mathrm{OH}$ in Frozen Halide-Nitrate Solutions: An Active Halogen Formation Mechanism?, J. Phys. Chem. A, 114, 6527-6533, doi:10.1021/jp102072t, 2010.

Abbatt, J. P. D., Thomas, J. L., Abrahamsson, K., Boxe, C., Granfors, A., Jones, A. E., King, M. D., Saiz-Lopez, A., Shepson, P. B., Sodeau, J., Toohey, D. W., Toubin, C., von Glasow, R., Wren, S. N., and Yang, X.: Halogen activation via interactions with environmental ice and snow in the polar lower troposphere and other regions, Atmos. Chem. Phys., 12, 6237-6271, doi:10.5194/acp-12-6237-2012, 2012.

Adams, J. W., Holmes, N. S., and Crowley, J. N.: Uptake and reaction of $\mathrm{HOBr}$ on frozen and dry $\mathrm{NaCl} / \mathrm{NaBr}$ surfaces between 253 and 233 K, Atmos. Chem. Phys., 2, 79-91, doi:10.5194/acp2-79-2002, 2002.

Apel, E., Emmons, L., Karl, T., Flocke, F., Hills, A., Madronich, S., Lee-Taylor, J., Fried, A., Weibring, P., and Walega, J.: Chemical evolution of volatile organic compounds in the outflow of the Mexico City metropolitan area, Atmos. Chem. Phys., 10, 23532375, doi:10.5194/acp-10-2353-2010, 2010.

Aranda, A., Le Bras, G., La Verdet, G., and Poulet, G.: The $\mathrm{BrO}^{+} \mathrm{CH}_{3} \mathrm{O}_{2}$ reaction: Kinetics and role in the atmospheric ozone budget, Geophys. Res. Lett., 24, 2745-2748, doi:10.1029/97GJ02686, 1997.

Ariya, P., Jobson, B., Sander, R., Niki, H., Harris, G., Hopper, J., and Anlauf, K.: Measurements of $\mathrm{C}_{2}-\mathrm{C}_{7}$ hydrocarbons during the Polar Sunrise Experiment 1994: Further evidence for halogen chemistry in the troposphere, J. Geophys. Res., 103, 1316913180, 1998.

Atkinson, R., Baulch, D. L., Cox, R. A., Crowley, J. N., Hampson, R. F., Hynes, R. G., Jenkin, M. E., Rossi, M. J., and Troe, J.: Evaluated kinetic and photochemical data for atmospheric chemistry: Volume $\mathrm{I}-$ gas phase reactions of $\mathrm{O}_{x}, \mathrm{HO}_{x}, \mathrm{NO}_{x}$ and $\mathrm{SO}_{x}$ species, Atmos. Chem. Phys., 4, 1461-1738, doi:10.5194/acp-41461-2004, 2004.

Atkinson, R., Baulch, D. L., Cox, R. A., Crowley, J. N., Hampson, R. F., Hynes, R. G., Jenkin, M. E., Rossi, M. J., Troe, J., and IUPAC Subcommittee: Evaluated kinetic and photochemical data for atmospheric chemistry: Volume II - gas phase reactions of organic species, Atmos. Chem. Phys., 6, 3625-4055, doi:10.5194/acp-6-3625-2006, 2006.

Atkinson, R., Baulch, D. L., Cox, R. A., Crowley, J. N., Hampson, R. F., Hynes, R. G., Jenkin, M. E., Rossi, M. J., and Troe, J.: Evaluated kinetic and photochemical data for atmospheric chemistry: Volume III - gas phase reactions of inorganic halogens, Atmos. Chem. Phys., 7, 981-1191, doi:10.5194/acp-7-981-2007, 2007.

Barrie, L., Bottenheim, J., Schnell, R., Crutzen, P., and Rasmussen, R.: Ozone destruction and photochemical reactions at polar sunrise in the lower Arctic atmosphere, Nature, 334, 138-141, doi:10.1038/334138a0, 1988.

Beckwith, R. C., Wang, T. X., and Margerum, D. W.: Equilibrium and kinetics of bromine hydrolysis, Inorg. Chem., 35, 995-1000, 1996.

Bottenheim, J. W., Barrie, L. A., Atlas, E., Heidt, L. E., Niki, H., Rasmussen, R. A., and Shepson, P. B.: Depletion of lower tropospheric ozone during Arctic spring: The Polar Sunrise Experiment 1998, J. Geophys. Res., 95, 18555-18568, 1990.

Calvert, J. G. and Lindberg, S. E.: Potential influence of iodinecontaining compounds on the chemistry of the troposphere in the polar spring. I. Ozone depletion, Atmos. Environ., 38, 50875104, doi:10.1016/j.atmosenv.2004.05.049, 2004.

Cao, L., Sihler, H., Platt, U., and Gutheil, E.: Numerical analysis of the chemical kinetic mechanisms of ozone depletion and halogen release in the polar troposphere, Atmos. Chem. Phys., 14, 37713787, doi:10.5194/acp-14-3771-2014, 2014.

Cavender, A. E., Biesenthal, T. A., Bottenheim, J. W., and Shepson, P. B.: Volatile organic compound ratios as probes of halogen atom chemistry in the Arctic, Atmos. Chem. Phys., 8, 17371750, doi:10.5194/acp-8-1737-2008, 2008.

Clyne, M. and Cruse, H.: Atomic resonance fluorescence spectrometry for the rate constants of rapid bimolecular reactions, Part 2. Reactions $\mathrm{Cl}^{+} \mathrm{BrCl}_{\mathrm{C}} \mathrm{Cl}^{+} \mathrm{Br}_{2}, \mathrm{Cl}^{+} \mathrm{ICl}, \mathrm{Br}^{+} \mathrm{IBr}, \mathrm{Br}^{+} \mathrm{ICl}, \mathrm{J}$. Chem. Soc., Faraday Trans. 2, 68, 1377-1387, 1972.

Custard, K. D., Thompson, C. R., Pratt, K. A., Shepson, P. B., Liao, J., Huey, L. G., Orlando, J. J., Weinheimer, A. J., Apel, E., Hall, S. R., Flocke, F., Mauldin, L., Hornbrook, R. S., Pöhler, D., General, S., Zielcke, J., Simpson, W. R., Platt, U., Fried, A., Weibring, P., Sive, B. C., Ullmann, K., Cantrell, C., Knapp, D. J., and Montzka, D. D.: The $\mathrm{NO}_{x}$ dependence of bromine chemistry in the Arctic atmospheric boundary layer, Atmos. Chem. Phys., 15, 10799-10809, doi:10.5194/acp-15-10799-2015, 2015.

Domine, F., Bock, J., Voisin, D., and Donaldson, D. J.: Can We Model Snow Photochemistry? Problems with the Current Approaches, J. Phys. Chem., A, 117, 4733-4749, doi:10.1021/jp3123314, 2013.

Edwards, G. D., Cantrell, C. A., Stephens, S., Hill, B., Goyea, O., Shetter, R. E., Mauldin III, R. L., Kosciuch, E., Tanner, D. J., and Eisele, F. L.: Chemical ionization mass spectrometer instrument for the measurement of tropospheric $\mathrm{HO}_{2}$ and $\mathrm{RO}_{2}$, Anal. Chem., 75, 5317-5327, doi:10.1021/ac034402b, 2003.

Ehhalt, D. H.: Photooxidation of trace gases in the troposphere Plenary Lecture, Phys. Chem. Chem. Phys., 1, 5401-5408, 1999.

Fan, S.-M. and Jacob, D. J.: Surface ozone depletion in Arctic spring sustained by bromine reactions on aerosols, Nature, 358, 522-524, 1992. 
Foster, K. L., Plastridge, R. A., Bottenheim, J. W., Shepson, P. B., Finlayson-Pitts, B. J., and Spicer, C. W.: The role of $\mathrm{Br}_{2}$ and $\mathrm{BrCl}$ in surface ozone destruction at polar sunrise, Science, 291, 471-474, 2001.

Fried, A., Sewell, S., Henry, B., Wert, B. P., and Gilpin, T.: Tunable diode laser absorption spectrometer for ground-based measurements of formaldehyde, J. Geophys. Res., 102, 6253-6266, doi:10.1029/96JD01580, 1997

Gladich, I., Francisco, J. S., Buszek, R. J., Vazdar, M., Caignano, M. A., and Shepson, P. B.: Ab Initio Study of the Reaction of Ozone with Bromide Ion, J. Phys. Chem. A, 119, 4482-4488, 2015.

Gong, S., Walmsley, J., Barrie, L., and Hopper, J.: Mechanisms for surface ozone depletion and recovery during polar sunrise, Atmos. Environ., 31, 969-981, 1997.

Guimbaud, C., Grannas, A. M., Shepson, P. B., Fuentes, J. D., Boudries, H., Bottenheim, J. W., Dominé, F., Houdier, S., Perrier, S., and Biesenthal, T. B.: Snowpack processing of acetaldehyde and acetone in the Arctic atmospheric boundary layer, Atmos. Environ., 36, 2743-2752, 2002.

Hansen, J. C., Li, Y., Li, Z., and Francisco, J. S.: On the mechanism of the $\mathrm{BrO}+\mathrm{HBr}$ reaction, Chem. Phys. Lett., 314, 341346, doi:10.1016/S0009-2614(99)01093-3, 1999.

Hausmann, M. and Platt, U.: Spectroscopic measurement of bromine oxide and ozone in the high Arctic during Polar Sunrise Experiment 1992, J. Geophys. Res., 99, 25399, doi:10.1029/94JD01314, 1994.

Helmig, D., Ganzeveld, L., Butler, T., and Oltmans, S. J.: The role of ozone atmosphere-snow gas exchange on polar, boundary-layer tropospheric ozone - a review and sensitivity analysis, Atmos. Chem. Phys., 7, 15-30, doi:10.5194/acp-7-15-2007, 2007.

Helmig, D., Boylan, P., Johnson, B., Oltmans, S., Fairall, C., Staebler, R., Weinheimer, A., Orlando, J., Knapp, D. J., Montzka, D. D., Flocke, F., Frieß, U., Sihler, H., and Shepson, P. B.: Ozone dynamics and snow-atmosphere exchanges during ozone depletion events at Barrow, Alaska, J. Geophys. Res., 117, D20303, doi:10.1029/2012JD017531, 2012.

Hirokawa, J., Onaka, K., Kajii, Y., and Akimoto, H.: Heterogeneous processes involving sodium halide particles and ozone: molecular bromine release in the marine boundary layer in the absence of nitrogen oxides, Geophys. Res. Lett., 25, 2449-2452, 1998.

Holmes, C. D., Jacob, D. J., Corbitt, E. S., Mao, J., Yang, X., Talbot, R., and Slemr, F.: Global atmospheric model for mercury including oxidation by bromine atoms, Atmos. Chem. Phys., 10, 12037-12057, doi:10.5194/acp-10-12037-2010, 2010.

Hönninger, G.: Halogen Oxide Studies in the Boundary Layer by Multi Axis Differential Optical Absorption Spectroscopy and Active Longpath-DOAS, PhD, University of Heidelberg, 2002.

Huff, A. K. and Abbatt, J. P. D.: Kinetics and product yields in the heterogeneous reactions of $\mathrm{HOBr}$ with ice surfaces containing $\mathrm{NaBr}$ and $\mathrm{NaCl}$, J. Phys. Chem. A, 106, 5279-5287, 2002.

Jacob, D. J.: Heterogeneous chemistry and tropospheric ozone, Atmos. Environ., 34, 2131-2159, 2000.

Jobson, B., Niki, H., Yokouchi, Y., Bottenheim, J., Hopper, F., and Leaitch, R.: Measurements of $\mathrm{C}_{2}-\mathrm{C}_{6}$ hydrocarbons during the Polar Sunrise 1992 Experiment: Evidence for $\mathrm{Cl}$ atom and $\mathrm{Br}$ atom chemistry, J. Geophys. Res., 99, 25355-25368, 1994.

Kukui, A., Kirchner, U., Benter, T., and Schindler, R. N.: A gas kinetic investigation of $\mathrm{HOBr}$ reactions with $\mathrm{Cl}\left({ }^{2} \mathrm{P}\right), \mathrm{O}\left({ }^{3} \mathrm{P}\right)$ and
$\mathrm{OH}\left({ }^{2} \mathrm{II}\right)$. The reaction of $\mathrm{BrCl}$ with $\mathrm{OH}\left({ }^{2} \mathrm{II}\right)$, Ber. Bunsen. Phys. Chem., 100, 455-461, 1996.

Kuo, K. K.: Principles of combustion, John Wiley \& Sons, New York, 1986.

Lancaster, D. G., Fried, A., Wert, B., Henry, B., and Tittel, F. K.: Difference-frequency-based tunable absorption spectrometer for detection of atmospheric formaldehyde, Appl. Optics, 39, 24, 4436-4443, doi:10.1364/AO.39.004436, 2000.

Lary, D.: Gas phase atmospheric bromine photochemistry, J. Geophys. Res., 101, 1505-1516, 1996.

Le Bras, G. and Platt, U.: A possible mechanism for combined chlorine and bromine catalyzed destruction of tropospheric ozone in the Arctic, Geophys. Res. Lett., 22, 599-602, 1995.

Lehrer, E., Hönninger, G., and Platt, U.: A one dimensional model study of the mechanism of halogen liberation and vertical transport in the polar troposphere, Atmos. Chem. Phys., 4, 2427 2440, doi:10.5194/acp-4-2427-2004, 2004.

Liao, J., Sihler, H., Huey, L. G., Neuman, J. A., Tanner, D. J., Friess, U., Platt, U., Flocke, F. M., Orlando, J. J., Shepson, P. B., Beine, H. J., Weinheimer, A. J., Sjostedt, S. J., Nowak, J. B., Knapp, D. J., Staebler, R. M., Zheng, W., Sander, R., Hall, S. R., and Ullmann, K.: A comparison of Arctic BrO measurements by chemical ionization mass spectrometry and long pathdifferential optical absorption spectroscopy, J. Geophys. Res., 116, D14, doi:10.1029/2010JD014788, 2011.

Liao, J., Huey, L. G., Scheuer, E., Dibb, J. E., Stickel, R. E., Tanner, D. J., Neuman, J. A., Nowak, J. B., Choi, S., Wang, Y., Salawitch, R. J., Canty, T., Chance, K., Kurosu, T., Suleiman, R., Weinheimer, A. J., Shetter, R. E., Fried, A., Brune, W., Anderson, B., Zhang, X., Chen, G., Crawford, J., Hecobian, A., and Ingall, E. D.: Characterization of soluble bromide measurements and a case study of BrO observations during ARCTAS, Atmos. Chem. Phys., 12, 1327-1338, doi:10.5194/acp-12-1327-2012, 2012a.

Liao, J., Huey, L., Tanner, D., Flocke, F., Orlando, J., Neuman, J., Nowak, J., Weinheimer, A., Hall, S., Smith, J., Fried, A., Staebler, R., Wang, Y., Koo, J.-H., Cantrell, C., Weibring, P., Walega, J., Knapp, D., Shepson, P., and Stephens, C.: Observations of inorganic bromine $\left(\mathrm{HOBr}, \mathrm{BrO}\right.$, and $\left.\mathrm{Br}_{2}\right)$ speciation at Barrow, Alaska, in spring 2009, J. Geophys. Res., 117, D00R16, doi:10.1029/2011JD016641, 2012b.

Liao, J., Huey, L. G., Liu, Z., Tanner, D. J., Cantrell, C. A., Orlando, J. J., Flocke, F. M., Shepson, P. B., Weinheimer, A. J., Hall, S. R., Beine, H. J., Wang, Y., Ingall, E. D., Stephens, C. R., Hornbrook, R. S., Apel, E., Fried, A., Mauldin, L., Smith, J. N., Staebler, R. M., Neuman, J. A., and Nowak, J. B.: High levels of molecular chlorine in the Arctic atmosphere, Nat. Geosci., 7, 91-94, doi:10.1038/ngeo2046, 2014.

Mahajan, A., Shaw, M., Oetjen, H., Hornsby, K., Carpenter, L., Kaleschke, L., Tian-Kunze, X., Lee, J., Moller, S., and Edwards, P.: Evidence of reactive iodine chemistry in the Arctic boundary layer, J. Geophys. Res., 115, D20303, doi:10.1029/2009JD013665, 2010.

Mallard, W. G., Westley, F., Herron, J. T., Hampson, R. F., and Frizzel, D. H.: NIST Chemical Kinetics Database: Version 5.0 National Institute of Standards and Technology, Gaithersburg, MD, 1993.

Martinez, M., Arnold, T., and Perner, D.: The role of bromine and chlorine chemistry for arctic ozone depletion events in $\mathrm{Ny}$ - 
Ålesund and comparison with model calculations, Ann. Geophys., 17, 941-956, doi:10.1007/s00585-999-0941-4, 1999.

McFiggans, G., Plane, J. M. C., Allan, B. J., Carpenter, L. J., Coe, H., and O'Dowd, C.: A modeling study of iodine chemistry in the marine boundary layer, J. Geophys. Res., 105, 14371-14385, 2000.

McFiggans, G., Cox, R. A., Mössinger, J. C., Allan, B. J., and Plane, J. M. C.: Active chlorine release from marine aerosols: Roles for reactive iodine and nitrogen species, J. Geophys. Res, 107, ACH 10-1-ACH 10-13, doi:10.1029/2001JD000383, 2002.

Michalowski, B. A., Francisco, J. S., Li, S. M., Barrie, L. A., Bottenheim, J. W., and Shepson, P. B.: A computer model study of multiphase chemistry in the Arctic boundary layer during polar sunrise, J. Geophys. Res., 105, 15131-15145, 2000.

Mielke, L. H., Furgeson, A., and Osthoff, H. D.: Observation of $\mathrm{ClNO}_{2}$ in a mid-continental urban environment, Environ. Sci. Technol., 45, 8889-8896, 2011.

Monks, P. S.: Gas-phase radical chemistry in the troposphere, Chem. Soc. Rev., 34, 376-395, 2005.

Neuman, J. A., Nowak, J. B., Huey, L. G., Burkholder, J. B., Dibb, J. E., Holloway, J. S., Liao, J., Peischl, J., Roberts, J. M., Ryerson, T. B., Scheuer, E., Stark, H., Stickel, R. E., Tanner, D. J., and Weinheimer, A.: Bromine measurements in ozone depleted air over the Arctic Ocean, Atmos. Chem. Phys., 10, 6503-6514, doi:10.5194/acp-10-6503-2010, 2010.

Orlando, J. J. and Tyndall, G. S.: Rate Coefficients for the Thermal Decomposition of BrONO2 and the Heat of Formation of BrONO2, J. Phys. Chem., 100, 19398-19405, doi:10.1021/jp9620274, 1996.

Oum, K., Lakin, M., and Finlayson-Pitts, B.: Bromine activation in the troposphere by the dark reaction of $\mathrm{O}_{3}$ with seawater ice, Geophys. Res. Lett., 25, 3923-3926, 1998 b.

Papanastasiou, D. K., McKeen, S. A., and Burkholder, J. B.: The very short-lived ozone depleting substance $\mathrm{CHBr}_{3}$ (bromoform): revised UV absorption spectrum, atmospheric lifetime and ozone depletion potential, Atmos. Chem. Phys., 14, 30173025, doi:10.5194/acp-14-3017-2014, 2014.

Piot, M. and von Glasow, R.: The potential importance of frost flowers, recycling on snow, and open leads for ozone depletion events, Atmos. Chem. Phys., 8, 2437-2467, doi:10.5194/acp-82437-2008, 2008.

Platt, U. and Janssen, C.: Observation and role of the free radicals $\mathrm{NO}_{3}, \mathrm{ClO}, \mathrm{BrO}$ and $\mathrm{IO}$ in the troposphere, Faraday Discuss., 100, 175-198, 1995.

Pöhler, D., Vogel, L., Frieß, U., and Platt, U.: Observation of halogen species in the Amundsen Gulf, Arctic, by active long-path differential optical absorption spectroscopy, P. Natl. Acad. Sci. USA, 107, 6582-6587, doi:10.1073/pnas.0912231107, 2010.

Pratt, K. A., Custard, K. D., Shepson, P. B., Douglas, T. A., Pöhler, D., General, S., Zielcke, J., Simpson, W. R., Platt, U., Tanner, D. J., Huey, L. G., Carlsen, M., and Stirm, B. H.: Photochemical production of molecular bromine in Arctic surface snowpacks, Nat. Geosci., 6, 351-356, doi:10.1038/ngeo1779, 2013.

Raso, A. R. W., Custard, K. D., Pratt, K. A., Tanner, D. J., Huey, L. G., and Shepson, P. B.: Active molecular iodine snowpack photochemistry in the Arctic, P. Natl. Acad. Sci. USA, in review, 2017.

Ridley, B., Grahek F., and Walega, J.: A small high-sensitivity, medium-response ozone detector suitable for measurements from light aircraft, J. Atmos. Oceanic Technol., 9, 142-148, 1992.

Russo, R., Zhou, Y., White, M., Mao, H., Talbot, R., and Sive, B.: Multi-year (2004-2008) record of nonmethane hydrocarbons and halocarbons in New England: Seasonal variations and regional sources, Atmos. Chem. Phys., 10, 4909-4929, doi:10.5194/acp10-4909-2010, 2010.

Ryerson, T. B., Williams, E. J., and Fehsenfeld, F. C.: An efficient photolysis system for fast-response $\mathrm{NO}_{2}$ measurements, $\mathrm{J}$. Geophys. Res., 105, 26447-26461, doi:10.1029/2000JD900389, 2000.

Saiz-Lopez, A., Plane, J. M. C., Mahajan, A. S., Anderson, P. S., Bauguitte, S. J.-B., Jones, A. E., Roscoe, H. K., Salmon, R. A., Bloss, W. J., Lee, J. D., and Heard, D. E.: On the vertical distribution of boundary layer halogens over coastal Antarctica: implications for $\mathrm{O}_{3}, \mathrm{HO}_{x}, \mathrm{NO}_{x}$ and the $\mathrm{Hg}$ lifetime, Atmos. Chem. Phys., 8, 887-900, doi:10.5194/acp-8-887-2008, 2008.

Sander, R., Vogt, R., Harris, G. W., and Crutzen, P. J.: Modelling the chemistry of ozone, halogen compounds, and hydrocarbons in the arctic troposphere during spring, Tellus B, 49, 522-532, 1997.

Sander, R., Keene, W. C., Pszenny, A. A. P., Arimoto, R., Ayers, G. P., Baboukas, E., Cainey, J. M., Crutzen, P. J., Duce, R. A., Hönninger, G., Huebert, B. J., Maenhaut, W., Mihalopoulos, N., Turekian, V. C., and Van Dingenen, R.: Inorganic bromine in the marine boundary layer: a critical review, Atmos. Chem. Phys., 3, 1301-1336, doi:10.5194/acp-3-1301-2003, 2003.

Sander, S. P., Golden, D., Kurylo, M., Moortgat, G., Wine, P., Ravishankara, A., Kolb, C., Molina, M., Finlayson-Pitts, B., and Huie, R.: Chemical kinetics and photochemical data for use in atmospheric studies evaluation number 15, http://hdl.handle.net/2014/ 41648, 2006.

Shetter, R. E. and Müller, M.: Photolysis frequency measurements using actinic flux spectroradiometry during the PEM-Tropics mission: Instrumentation description and some results, J. Geophys. Res., 104, 5647-5661, 1999.

Shepson, P. B., Sirju, A.-P., Hopper, J. F., Barrie, L. A., Young, V., Niki, H., and Dryfhout, H.: Sources and sinks of carbonyl compounds in the Arctic Ocean boundary layer: a polar ice floe experiment, J. Geophys. Res., 101, 21081-21089, 1996.

Staebler, R. M., den Hartog, G., Georgi, B., and Sterdiek, T. D.: Aerosol size distribution in Arctic haze during the Polar Sunrise Experiment 1992, J. Geophys. Res., 99, 25429-25437, 1994.

Sumner, A. L., and Shepson, P. B.: Snowpack production of formaldehyde and its effect on the Arctic troposphere, Nature, 398, 230-233, 1999.

Stephens, C. R., Shepson, P. B., Steffen, A., Bottenheim, J. W., Liao, J., Huey, L. G., Apel, E., Weinheimer, A., Hall, S. R., and Cantrell, C.: The relative importance of chlorine and bromine radicals in the oxidation of atmospheric mercury at Barrow, Alaska, J. Geophys. Res., 117, D00R11, doi:10.1029/2011JD016649, 2012.

Sturges, W. and Barrie, L.: Chlorine, bromine and iodine in Arctic aerosols, Atmos. Environ., 22, 1179-1194, 1988.

Tang, T. and McConnell, J.: Autocatalytic release of bromine from Arctic snow pack during polar sunrise, Geophys. Res. Lett., 23, 2633-2636, 1996.

Thomas, J. L., Stutz, J., Lefer, B., Huey, L. G., Toyota, K., Dibb, J. E., and von Glasow, R.: Modeling chemistry in and above snow 
at Summit, Greenland - Part 1: Model description and results, Atmos. Chem. Phys., 11, 4899-4914, doi:10.5194/acp-11-48992011, 2011.

Thompson, C. R., Shepson, P. B., Liao, J., Huey, L. G., Apel, E. C., Cantrell, C. A., Flocke, F., Orlando, J., Fried, A., Hall, S. R., Hornbrook, R. S., Knapp, D. J., Mauldin III, R. L., Montzka, D. D., Sive, B. C., Ullmann, K., Weibring, P., and Weinheimer, A.: Interactions of bromine, chlorine, and iodine photochemistry during ozone depletions in Barrow, Alaska, Atmos. Chem. Phys., 15, 9651-9679, doi:10.5194/acp-15-9651-2015, 2015.

Thornton, J. A., Kercher, J. P., Riedel, T. P., Wagner, N. L., Cozic, J., Holloway, J. S., Dubé, W. P., Wolfe, G. M., Quinn, P. K., Middlebrook, A. M., Alexander, B., and Brown, S. S.: A large atomic chlorine source inferred from mid-continental reactive nitrogen chemistry, Nature, 464, 271-274, 2010.

Toyota, K., McConnell, J. C., Lupu, A., Neary, L., McLinden, C. A., Richter, A., Kwok, R., Semeniuk, K., Kaminski, J. W., Gong, S.-L., Jarosz, J., Chipperfield, M. P., and Sioris, C. E.: Analysis of reactive bromine production and ozone depletion in the Arctic boundary layer using 3-D simulations with GEM-AQ: inference from synoptic-scale patterns, Atmos. Chem. Phys., 11, 3949-3979, doi:10.5194/acp-11-3949-2011, 2011.

Toyota, K., McConnell, J. C., Staebler, R. M., and Dastoor, A. P.: Air-snowpack exchange of bromine, ozone and mercury in the springtime Arctic simulated by the 1-D model PHANTAS - Part 1: In-snow bromine activation and its impact on ozone, Atmos. Chem. Phys., 14, 4101-4133, doi:10.5194/acp-14-4101$2014,2014$.
Troy, R. C., Kelley, M. D., Nagy, J. C., and Margerum, D. W. Non-metal redox kinetics: Iodine monobromide reaction with iodide ion and the hydrolysis of IBr, Inorg. Chem., 30, 4838-4845, 1991.

Vogt, R., Crutzen, P. J., and Sander, R.: A mechanism for halogen release from sea-salt aerosol in the remote marine boundary layer, Nature, 383, 327-330, doi:10.1038/383327a0, 1996.

Wallington, T. J., Skewes, L. M., Siegl, W. O., and Japar, S. M.: A relative rate study of the reaction of bromine atoms with a variety of organic compounds at $295 \mathrm{~K}$, Int. J. Chem. Kinet., 21, 10691076, 1989.

Wang, T. X., Kelley, M. D., Cooper, J. N., Beckwith, R. C., and Margerum, D. W.: Equilibrium, kinetic, and UV-spectral characteristics of aqueous bromine chloride, bromine, and chlorine species, Inorg. Chem., 33, 5872-5878, 1994.

Wennberg, P., Hanisco, T., Jaegle, L., Jacob, D., Hintsa, E., Lanzendorf, E., Anderson, J., Gao, R. S., Keim, E., and Donnelly, S.: Hydrogen radicals, nitrogen radicals, and the production of $\mathrm{O}_{3}$ in the upper troposphere, Science, 279, 49-53, 1998.

Young, C. J., Washenfelder, R. A., Roberts, J. M., Mielke, L. H., Osthoff, H. D., Tsai, C., Pikelnayai, O., Stutz, J., Veres, P. R., Cochran, A. K., VandenBoer, T. C., Flynn, J., Grossberg, N., Haman, C. L., Lefer, B., Stark, H., Graus, M., de Gouw, J., Gilman, J. B., Kuster, W. C., and Brown, S. S.: Vertically resolved measurements of nighttime radical reservoirs in Los Angeles and their contribution to the urban radical budget, Environ. Sci. Technol., 46, 10965-10973, 2012.

Zeng, T., Wang, Y., Chance, K., Blake, N., Blake, D., and Ridley, B.: Halogen-driven low-altitude $\mathrm{O}_{3}$ and hydrocarbon losses in spring at northern high latitudes, J. Geophys. Res., 111, D17313, doi:10.1029/2005JD006706, 2006. 